\title{
Progressive NKCC1-Dependent Neuronal Chloride Accumulation during Neonatal Seizures
}

\author{
Volodymyr I. Dzhala, ${ }^{1 \star}$ Kishore V. Kuchibhotla, ${ }^{1,3 \star}$ Joseph C. Glykys, ${ }^{1}$ Kristopher T. Kahle, ${ }^{2}$ Waldemar B. Swiercz, ${ }^{1}$ \\ Guoping Feng, ${ }^{4}$ Thomas Kuner, ${ }^{4}$ George J. Augustine, ${ }^{4}$ Brian J. Bacskai, ${ }^{1}$ and Kevin J. Staley ${ }^{1}$ \\ Departments of ${ }^{1}$ Neurology and ${ }^{2}$ Neurosurgery, Massachusetts General Hospital and Harvard Medical School, Boston, Massachusetts 02114, ${ }^{3}$ Program in \\ Biophysics, Harvard University, Cambridge, Massachusetts 02138, and ${ }^{4}$ Department of Neurobiology, Duke University Medical Center, Durham, North \\ Carolina 27710
}

Seizures induce excitatory shifts in the reversal potential for $\mathrm{GABA}_{\mathrm{A}}$-receptor-mediated responses, which may contribute to the intractability of electro-encephalographic seizures and preclude the efficacy of widely used GABAergic anticonvulsants such as phenobarbital. We now report that, in intact hippocampi prepared from neonatal rats and transgenic mice expressing Clomeleon, recurrent seizures progressively increase the intracellular chloride concentration $\left(\left[\mathrm{Cl}^{-}\right]_{\mathrm{i}}\right)$ assayed by Clomeleon imaging and invert the net effect of $\mathrm{GABA}_{\mathrm{A}}$

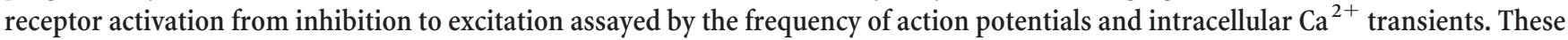
changes correlate with increasing frequency of seizure-like events and reduction in phenobarbital efficacy. The $\mathrm{Na}^{+}-\mathrm{K}^{+}-2 \mathrm{Cl}^{-}(\mathrm{NKCCl})$ cotransporter blocker bumetanide inhibited seizure-induced neuronal $\mathrm{Cl}^{-}$accumulation and the consequent facilitation of recurrent seizures. Our results demonstrate a novel mechanism by which seizure activity leads to $\left[\mathrm{Cl}^{-}\right]_{\mathrm{i}}$ accumulation, thereby increasing the probability of subsequent seizures. This provides a potential mechanism for the early crescendo phase of neonatal seizures.

\section{Introduction}

Neurons respond to a variety of stimuli with long-term shifts in the reversal potential for $\mathrm{GABA}_{\mathrm{A}}$ receptor $\left(\mathrm{GABA}_{\mathrm{A}}-\mathrm{R}\right)$-mediated postsynaptic currents $\left(E_{\mathrm{GABA}}\right)$. For example, epileptogenic injuries alter neuronal chloride transport, which is the principal determinant of $E_{\mathrm{GABA}}$ (Jin et al., 2005; Pathak et al., 2007). $E_{\mathrm{GABA}}$ is persistently shifted to more positive (depolarizing) potentials by prolonged seizure activity (Khalilov et al., 2003) or trains of action potentials without (Fiumelli and Woodin, 2007; Brumback and Staley, 2008) or with concomitant $\mathrm{GABA}_{\mathrm{A}}$ receptor activation (Woodin et al., 2003). In addition, other events, including oxygen-glucose deprivation (Pond et al., 2006) and trauma (van den Pol et al., 1996), shift $E_{\mathrm{GABA}}$ to more depolarized potentials. Depolarized values of $E_{\mathrm{GABA}}$ reduce the efficacy of inhibition and contribute to seizure activity (Dzhala and Staley, 2003; Khazipov et al., 2004; Dzhala et al., 2005).

Immature neurons express high levels of NKCC1 (Delpire, 2000; Wang et al., 2002; Dzhala et al., 2005), an electroneutral cotransporter that imports $\mathrm{Na}^{+}, \mathrm{K}^{+}$, and $\mathrm{Cl}^{-}$. This raises the intracellular chloride concentration, resulting in a depolarized $E_{\mathrm{GABA}}$. This shift in $E_{\mathrm{GABA}}$ can initiate a positive feedback cycle in

\footnotetext{
Received April 6, 2010; revised July 7, 2010; accepted July 12, 2010.

This work was supported by the National Institutes of Health (NIH)/National Institute of Neurological Disorders and Stroke Grant NS $40109-06$ (K.J.S.), NIH Grants EB000768 (B.J.B.) and NS580752 (K.V.K.), an American Epilepsy Society grant (J.C.G.), and a Hearst Foundation grant (V.I.D.)

*V.I.D. and K.V.K. contributed equally to this work.

Correspondence should be addressed to Dr. Kevin J. Staley, Department of Neurology, MassGeneral Institute for Neurodegenerative Disease, Massachusetts General Hospital, 16th Street, CNY B-114, Room 2600, Charlestown, MA 02129. E-mail: kstaley@partners.org.

DOI:10.1523/JNEUROSCI.1769-10.2010

Copyright $\odot 2010$ the authors $\quad 0270-6474 / 10 / 3011745-17 \$ 15.00 / 0$
}

neonatal seizures (Staley and Smith, 2001), and depolarized values of $E_{\mathrm{GABA}}$ contribute to the reduced efficacy of GABAenhancing anticonvulsants (Dzhala et al., 2005, 2008) that are first-line agents in the treatment of neonatal seizures (Rennie and Boylan, 2003; Carmo and Barr, 2005). NKCC1 is selectively blocked by low micromolar concentrations of the loop diuretic bumetanide (Isenring et al., 1998; Hannaert et al., 2002). By reducing intracellular chloride accumulation, this diuretic shifts $E_{\mathrm{GABA}}$ to negative potentials, resulting in more effective inhibition (Yamada et al., 2004; Dzhala et al., 2005, 2008; Sipila et al., 2006; Rheims et al., 2008). The increase in inhibition has a significant anticonvulsant effect that is synergistic with anticonvulsants such as barbiturates that prolong the open probability of the $\mathrm{GABA}_{\mathrm{A}}$-receptor-mediated chloride channels (Twyman et al., 1989; Dzhala et al., 2005, 2008).

Several recent reports regarding the experimental treatment of neonatal seizures have reported conflicting results (Table 1). For example, if administered soon after the onset of seizures, phenobarbital is relatively more effective (Quilichini et al., 2003; Raol et al., 2009) and bumetanide is less effective (Kilb et al., 2007) as an anticonvulsant. In contrast, experiments in which drugs are administered after many seizures demonstrate reduced phenobarbital efficacy and increased efficacy of drugs such as bumetanide that block NKCC1-mediated shifts in $E_{\mathrm{GABA}}$ (Dzhala et al., 2005, 2008; Mazarati et al., 2009). Here we consider the possibility that activity-dependent, NKCC1-dependent changes in $E_{\mathrm{GABA}}$ help determine the time course of neonatal seizures. This hypothesis could explain the substantial variations in the efficacy of GABAergic anticonvulsants in the experimental settings described in Table 1. This hypothesis is also of considerable clinical importance because it provides an additional impetus for 
Table 1. Efficacy of GABAergic anticonvulsants in animal models of neonatal seizures

\begin{tabular}{|c|c|c|c|c|c|c|c|}
\hline \# & Preparation/model & Age & Anticonvulsant (AED) & Concentration & Application & Efficacy & Authors \\
\hline 1 & In vivo/flurothyl & P9, P15 & Phenobarbital & $20 \mathrm{mg} / \mathrm{kg}$ & Pretreatment (i.p) & High & (Velísek et al., 1995) \\
\hline 2 & In vivo/pentylenetetrazol & P7, P12 & Clobazam & $0.5-7.5 \mathrm{mg} / \mathrm{kg}$ & Pretreatment (i.p) & High & (Haugvicová et al., 1999) \\
\hline \multirow[t]{2}{*}{3} & \multirow[t]{2}{*}{ In vitro/0 $\mathrm{mm} \mathrm{Mg}^{2+}$} & \multirow[t]{2}{*}{ P7-P8 } & Phenobarbital & $30 \mu \mathrm{M}$ & \multirow[t]{2}{*}{ After 3 ILDs } & Low & \multirow[t]{2}{*}{ (Quilichini et al., 2003) } \\
\hline & & & Phenobarbital & $100 \mu \mathrm{M}$ & & High & \\
\hline 4 & In vitro; in vivo $/ \mathrm{K}^{+}+$gabazine & P8-P12,P17-P21 & Diazepam & $5 \mu \mathrm{M}$ & Coinjection (before ILD) & High & (Isaev et al., 2007) \\
\hline 5 & In vitro/0 mm Mg ${ }^{2+}$ & P4-P6 & Phenobarbital & $100 \mu \mathrm{M}$ & After 7 ILDs & Low & (Dzhala et al., 2008) \\
\hline \multirow[t]{2}{*}{6} & \multirow[t]{2}{*}{ In vitro/8.5 $\mathrm{mm} \mathrm{K}^{+}$; in vivo/kainic acid } & P5-P7 & Phenobarbital & $100 \mu \mathrm{M}$ & \multirow[t]{2}{*}{ After 7 ILDs pretreatment (i.p) } & Low & \multirow[t]{2}{*}{ (Dzhala et al., 2005) } \\
\hline & & P9-P12 & Phenobarbital & $25 \mathrm{mg} / \mathrm{kg}$ & & Modest & \\
\hline \multirow[t]{2}{*}{7} & \multirow[t]{2}{*}{ In vivo/kainic acid; flurothyl } & P10 & Phenobarbital & $50 \mathrm{mg} / \mathrm{kg}$ & \multirow[t]{2}{*}{ Stage 5 seizures (i.p) } & Significant & \multirow[t]{2}{*}{ (Raol et al., 2009) } \\
\hline & & P10 & Diazepam & $4-16 \mathrm{mg} / \mathrm{kg}$ & & Transient & \\
\hline
\end{tabular}

ILD, Ictal-like discharges; AED, antiepileptic drug.

immediate and aggressive treatment of neonatal seizures: the more seizures that occur, the more $E_{\mathrm{GABA}}$ will shift, and the lower the probability that the seizures will respond to available anticonvulsants such as phenobarbital, particularly during the crescendo phase of neonatal seizures (Painter et al., 1999). A corollary of this hypothesis is that, by blocking NKCC1, bumetanide should prevent or reduce the seizure-induced shift in $E_{\mathrm{GABA}}$, potentially ameliorating the crescendo pattern of neonatal seizures. Finally, enhancement of the efficacy of GABAergic anticonvulsants by bumetanide should increase with the duration of the previous seizure activity. These hypotheses are tested in whole hippocampal preparations from neonatal rats and CLM-1 mice.

\section{Materials and Methods}

Animals. All animal-use protocols conformed to the guidelines of the National Institutes of Health and the Massachusetts General Hospital Center for Comparative Medicine on the use of laboratory animals.

In vitro electrophysiology. Intact hippocampal formations were prepared from neonatal postnatal day 5 (P5) to P7 male and female CLM-1 mice pups and P3-P6 Sprague Dawley rat male pups as described previously (Dzhala et al., 2008). Animals were anesthetized and decapitated. The brain was rapidly removed to oxygenated $\left(95 \% \mathrm{O}_{2}-5 \% \mathrm{CO}_{2}\right)$ icecold $\left(2-5^{\circ} \mathrm{C}\right)$ artificial CSF (ACSF) containing the following (in mM): 126 $\mathrm{NaCl}, 3.5 \mathrm{KCl}, 2 \mathrm{CaCl}_{2}, 1.3 \mathrm{MgCl}_{2}, 25 \mathrm{NaHCO}_{3}, 1.2 \mathrm{NaH}_{2} \mathrm{PO}_{4}$, and 11 glucose, $\mathrm{pH}$ 7.4. The hemispheres were separated, and, after removing the cerebellum, the frontal part of the neocortex, and surrounding structures, the intact hippocampi were dissected from the septohippocampal complex. The hippocampi were incubated in oxygenated ACSF at room temperature $\left(20-22^{\circ} \mathrm{C}\right)$ for $1-2 \mathrm{~h}$ before use. For recordings, the hippocampi were placed into a conventional submerged chamber and continuously superfused with oxygenated ACSF at $32^{\circ} \mathrm{C}$ and at a flow rate $4 \mathrm{ml} / \mathrm{min}$.

Extracellular field potentials were recorded in the intact hippocampal preparations in vitro using tungsten microelectrodes and low-noise multichannel amplifier (bandpass, $0.1 \mathrm{~Hz}$ to $10 \mathrm{kHz} ; 1000 \times$ ) (supplemental Fig. 1, available at www.jneurosci.org as supplemental material). Microelectrodes made from coated tungsten wire of $50 \mu \mathrm{m}$ diameter (California Fine Wire Company) were used for simultaneous recordings of population field activity in EEG band $(0.1-100 \mathrm{~Hz})$, ripple $(100-200 \mathrm{~Hz})$, and fast ripple $(200-500 \mathrm{~Hz})$ oscillations and multiple-unit activity (MUA) $(500 \mathrm{~Hz}$ high-pass filter). Root mean square (RMS) noise level with an electrode placed in the perfusion solution was typically $3-4 \mu \mathrm{V}$, whereas the amplitude of action potentials recorded from the pyramidal cell layer ranged from this noise level up to $60-80 \mu \mathrm{V}$. The signals were digitized using an analog-to-digital converter (DigiData 1322A; Molecular Devices). Sampling interval per signal was $100 \mu \mathrm{s}$ (10 kHz). pClamp 9.2 (Molecular Devices), Mini Analysis 5.6 (Synaptosoft), and Origin 7.5 SR6 (Microcal Software) programs were used for the acquisition and data analysis. Power spectrum analysis was performed after applying a Hamming window function. Power was calculated by integrating the RMS value of the signal in frequency bands from 1 to $1000 \mathrm{~Hz}$.
Group measures are expressed as mean \pm SEM; error bars also indicate SEM. Statistical tests of significance were assessed with Student's $t$, ANOVA, $\chi^{2}$, and Mann-Whitney tests as indicated in Results. The level of significance was set at $p<0.05$.

Clomeleon imaging and $\left[\mathrm{Cl}^{-}\right]_{i}$ determination. Clomeleon is a fusion protein comprising the $\mathrm{Cl}^{-}$-sensitive yellow fluorescent protein (YFP) and the $\mathrm{Cl}^{-}$-insensitive cyan fluorescent protein (CFP). Transgenic CLM-1 mice expressing Clomeleon were received from Duke University Medical Center (Durham, NC) and housed at Massachusetts General Hospital Center for Comparative Medicine (Charlestown, MA). Intact hippocampi were prepared from neonatal (P5-P7) mice as described previously (Dzhala et al., 2008). The hippocampi were incubated in oxygenated ACSF at room temperature $\left(20-22^{\circ} \mathrm{C}\right)$ for at least $1 \mathrm{~h}$ before use. For optical imaging and simultaneous extracellular field potential recordings, the hippocampus was placed into a conventional submerged chamber on a precision $x-y$ stage mounted on the microscope and continuously superfused with oxygenated ACSF at $32^{\circ} \mathrm{C}$ and at a flow rate $4 \mathrm{ml} / \mathrm{min}$. Two-photon Clomeleon imaging was performed on an Olympus Fluoview 1000MPE with pre-chirp excitation optics and a fast acousto-optical modulator mounted on an Olympus BX61WI upright microscope using an Olympus $20 \times$ water-immersion objective (XLUMPLFL 20xW; numerical aperture, 0.95). A mode-locked titanium/sapphire laser (MaiTai; Spectra Physics) generated two-photon fluorescence with $860 \mathrm{~nm}$ excitation. Emitted light passed through a dichroic mirror (460 nm cutoff) and was bandpass filtered through one of two emission filters $480 \pm 15 \mathrm{~nm}$ (D480/30) for CFP and $535 \pm 20 \mathrm{~nm}$ (D535/40) for YFP (FV10MP-MC/Y). Detectors containing two photomultiplier tubes were used. Image size $(x-y$ dimension) was $512 \times 512$ pixel or unit converted $634.662 \times 634.662 \mu \mathrm{m}$. Clomeleon expressing neurons were typically sampled $20-200 \mu \mathrm{m}$ below the surface of the intact hippocampus ( $z$ dimension, $0-200 \mu \mathrm{m}$; step size, $2.00 \mu \mathrm{m})$. In ictal experiments, Clomelon imaging was performed $1 \mathrm{~min}$ after seizure termination to minimize $\mathrm{pH}$-related changes in fluorescence (Xiong et al., 2000). Peak ictal changes in $\mathrm{pH}$ in vitro are $\sim 0.02 \mathrm{pH}$ units (Xiong et al., 2000), which would cause $\leq 2 \mathrm{~mm}$ change in our estimates of intracellular chloride concentration $\left(\left[\mathrm{Cl}^{-}\right]_{\mathrm{i}}\right)$ (Kuner and Augustine, 2000).

Quantitative measurements on three-dimensional (3D) stacks were performed using NIH ImageJ $1.40 \mathrm{~g}$ software. The CFP and YFP images were opened, and their respective background value was subtracted for the $3 \mathrm{D}$ volume. Median filtering was applied to all of the $3 \mathrm{D}$ planes. Cells were visually identified, and a region of interest was drawn around the cell bodies. The ratio of the YFP/CFP fluorescence intensity was measured for each identified cell. The $\left[\mathrm{Cl}^{-}\right]_{\mathrm{i}}$ was calculated from the following equation:

$$
\left[\mathrm{Cl}^{-}\right]_{i}=K_{D}^{\prime} \frac{\left(R_{\max }-R\right)}{\left(R-R_{\min }\right)},
$$

where $R$ is the measured YFP/CFP ratio, $K_{D}^{\prime}$ is the apparent dissociation constant of Clomeleon, $R_{\max }$ is the ratio when Clomeleon is not bound by $\mathrm{Cl}^{-}$, and $R_{\min }$ when it is completely quenched by $F^{-}$(Kuner and Augustine, 2000; Berglund et al., 2008). The constants $K_{D}^{\prime}, R_{\max }$, and $R_{\min }$ were determined from the calibration of $\left[\mathrm{Cl}^{-}\right]_{\mathrm{i}}$ using solutions of known 
concentrations of $\mathrm{Cl}^{-}$[20, 80, and $123 \mathrm{~mm}$ extracellular chloride concentration $\left.\left(\left[\mathrm{Cl}^{-}\right]_{\mathrm{o}}\right)\right]$. The $\mathrm{K}^{+} / \mathrm{H}^{+}$ionophore nigericin $(50 \mu \mathrm{M})$ and the $\mathrm{Cl}^{-} / \mathrm{OH}^{-}$antiporter tributyltin chloride $(100 \mu \mathrm{M})$ were used to remove transmembrane $\mathrm{H}^{+} / \mathrm{OH}^{-}$and $\mathrm{Cl}^{-}$gradients. Neurons that experienced a change in YFP/CFP intensity to each $\left[\mathrm{Cl}^{-}\right]_{0}$ were used for the calibrations. The data points obtained with the different $\left[\mathrm{Cl}^{-}\right]_{\mathrm{o}}$ are described by rewriting the equation above as the ratiometric function:

$$
R=\frac{K_{D}^{\prime} \times R_{\max }+\left[\mathrm{Cl}^{-}\right] \times R_{\min }}{\left[\mathrm{Cl}^{-}\right]+K_{D}^{\prime}}
$$

where $R_{\max }$ and $K_{D}^{\prime}$ were free parameters, whereas $R_{\min }$ was determined by quenching Clomeleon with $123 \mathrm{~mm} F^{-}$(Kuner and Augustine, 2000; Duebel et al., 2006). With single-cell resolution, $R_{\max }$ and $K_{D}^{\prime}$ were calculated for 47 individual neurons that were followed across all calibration conditions. The $K_{D}^{\prime}$ was $91 \pm 5.43 \mathrm{mM}, R_{\max }$ was 1.026 , and $R_{\text {min }}$ was 0.268 .

The mean of the logarithmic value of the $\left[\mathrm{Cl}^{-}\right]_{\mathrm{i}}$ was used in pseudocolor images, because the ion concentration follows a log-normal distribution. $E_{\mathrm{Cl}}$ was calculated using the Nernst equation setting the temperature variable at $33^{\circ} \mathrm{C}$

Two-photon fluorescence $\mathrm{Ca}^{2+}$ imaging. Both excitatory and inhibitory GABA responses are evident during status epilepticus in the intact hippocampus in vitro. The dense packing of cells in the pyramidal layer makes it difficult to directly measure these differential activitydependent responses of individual neurons using extracellular recordings of multiple-unit activity. Two-photon fluorescence imaging of bulk-loaded calcium dyes provides an optical proxy to single-cell electrophysiology with the inherent ability to multiplex. Simultaneous investigation of hundreds of neurons with single-cell resolution (supplemental Fig. 1, available at www.jneurosci.org as supplemental material) makes it possible to determine whether the responses to GABA indeed vary from cell to cell and, more importantly, how this response topology shifts after recurrent seizures. The high spatial resolution of this technique allowed us, in many instances, to follow the same cells across multiple conditions, e.g., in control versus during and after spontaneous seizures, allowing us to use an individual cell as its own control.

We loaded hippocampal neurons with a calcium-sensitive dye under visual guidance through the two-photon microscope. A total of $0.8 \mathrm{~mm}$ Oregon Green 488 BAPTA-1 AM (OGB) was dissolved in DMSO with $20 \%$ pluronic acid and mixed in ACSF containing sulforhodamine 101 (SR-101), a red-fluorescent astrocyte-specific marker (all from Invitrogen). A 2-3 $\mu \mathrm{m}$ patch pipette was filled with this solution and inserted into the intact hippocampus to a depth of $150-300 \mathrm{~mm}$ from the surface. The AM dye, combined with SR-101, was pressure ejected from the pipette (5-20 psi for 60-150 s) under continuous visual guidance with multiphoton microscopy. OGB is not fluorescent until fully hydrolyzed inside a cell; as a result, the size of the microinjection was estimated using the red fluorescent signal from SR-101. Full loading of the OGB dye took $0.5-1 \mathrm{~h}$. After confirming loading, the pipette was withdrawn. Several hundred to thousands of cells were loaded from a single injection in a $300-\mu \mathrm{m}$-diameter spherical region.

Time-lapsed two-photon calcium imaging was performed on the same microscope used for Clomeleon imaging. For continuous visual guidance during dye loading, an Olympus $40 \times$ (numerical aperture, 0.80 ) was also used. OGB-loaded neurons were typically sampled 50-200 $\mu \mathrm{m}$ below the surface of the intact neonatal hippocampus.

Image analysis. Time-lapsed images were analyzed in NIH ImageJ (Wayne Rasband, National Institutes of Health, Bethesda, MD), Matlab (MathWorks), and Microsoft Office Excel using custom-written software. Cells were automatically identified, and time course data were extracted for each individual cell. On average, $>200$ neurons could be imaged simultaneously in a given experiment. Astrocytes could be identified based on their uptake of SR-101. Cells were defined as responsive if there was a significant difference their baseline fluorescence and the fluorescence immediately after electrical stimulation. The peak response of the cell was defined as the maximum $\Delta F / F$ immediately after stimulation. Cells were considered to be inhibited by GABA if their response to stim- ulus during application of kynurenic acid (KYNA) + CGP 55845 [(2S) 3-[(15)-1-(3,4-dichlorophenyl)ethyl] amino-2-hydroxypropyl) (phenylmethyl)phosphinic acid] + SR 95531 [2-(3-carboxypropyl)3-amino-6-(4-methoxyphenyl)pyridazinium bromide] (a potent $\mathrm{GABA}_{\mathrm{A}}-\mathrm{R}$ antagonist) significantly exceeded that under KYNA + CGP 55845 alone. In a subset of experiments, we were able to follow the same cells over the course of several hours to permit comparison across seizure and pharmacological conditions for the same cells. Before and after seizures, cells responses in three conditions (control, KYNA + CGP 55845, and KYNA + CGP 55845 + SR 95531) were compared. If cells were inhibited by GABA, there would be a change in binary response probability (from inactive to active) or peak intensity ( $>15 \%$ increase) when comparing the KYNA + CGP 55845 + SR 95531 condition to KYNA only. In total, we were able to analyze 468 cells in this manner. Of those that were inhibited by GABA ( $n=423$ neurons), we then determined the percentage that changed their polarity ("switched"), i.e., how many cells that were initially inhibited by GABA shifted their response after spontaneous seizures. We did this by comparing the cellular response properties from before and after seizure (again using both binary response probability and peak $\Delta F / F$ ). Finally, because we had single-cell resolution across conditions, we correlated the probability of a single cell "switching" to the initial response characteristic (peak $\Delta F / F$ ) during control conditions before spontaneous seizures. We grouped cells based on their initial evoked response to electrical stimulus in control conditions and created a probability distribution based on this simple formula: number of cells that switched/total number of cells. We then determined whether there was a correlation between initial evoked response and the probability of switching.

Phospho-NKCC1 Western blotting. Lysates were fractionated using $4-15 \%$ SDS-PAGE gradient gel electrophoresis (Bio-Rad). Proteins were transferred to a polyvinylidene difluoride membrane (Bio-Rad) at $100 \mathrm{~V}$ and $4^{\circ} \mathrm{C}$ for $2 \mathrm{~h}$. The membrane was then blocked in $10 \%$ nonfat dried milk in PBS with $0.1 \%$ Tween 20 (PBS-T). Primary antibodies, including rabbit R5 anti-phospho-NKCC1 (Flemmer et al., 2002) (gift from Dr. Biff Forbush, Yale University, New Haven, CT) and rabbit anti- $\beta$ tubulin (Cell Signaling Technology) were diluted, both at 1:500, in 5\% milk in PBS-T and incubated with the membrane for $1 \mathrm{~h}$ at room temperature. Blots were washed in PBS with $0.1 \%$ Tween 20 and probed with an HRP-conjugated anti-rabbit secondary antibody (Zymed) in 1\% milk in PBS-T for $30 \mathrm{~min}$ at room temperature. The filter was then washed and chemiluminescence was performed using ECL-Plus (GE Healthcare), following standard protocols.

Drugs. Reagents were purchased from Sigma-Aldrich and Tocris Cookson, prepared as stock solutions, and stored before use as aliquots in tightly sealed vials at the temperatures and conditions recommended by the manufacturers. Fluorescent probes were from Invitrogen.

Supplemental data. Supplemental Figures 1-5 are available at www. jneurosci.org as supplemental material.

\section{Results}

We used the intact hippocampal preparation (Khalilov et al., 1997) to preserve the neuronal network and avoid potential alterations in chloride transport and intracellular chloride concentration related to neuronal injury and axotomy (van den Pol et al., 1996; Nabekura et al., 2002) that may occur during slice preparation.

\section{Distribution of resting $\left[\mathrm{Cl}^{-}\right]_{\mathrm{i}}$ and GABA action in the intact neonatal hippocampus}

High-resolution two-photon fluorescence chloride imaging was performed in the intact hippocampus in vitro of the neonatal (P5-P7) transgenic CLM-1 mice expressing Clomeleon (Kuner and Augustine, 2000; Berglund et al., 2008; Glykys et al., 2009). The ratio of fluorescence resonance energy transfer-dependent emission of the chloride-sensitive YFP to the chloride-insensitive CFP was used to measure $\left[\mathrm{Cl}^{-}\right]_{\mathrm{i}}$ in CA3 pyramidal cells and interneurons (see Materials and Methods) (Fig. 1a,b). Under 
control conditions, the resting $\left[\mathrm{Cl}^{-}\right]_{\mathrm{i}}$ in the individual neurons of the intact hippocampal preparations $(n=10$ hippocampi) varied from 1 to $40 \mathrm{~mm}$ (Fig. 1) depending on cell size, type (data not shown), and postnatal age (Tyzio et al., 2007; Glykys et al., 2009). Gaussian fits revealed a wide range of the resting intracellular chloride (Fig. 1b), suggesting heterogeneous populations of neurons, some with an $E_{\mathrm{Cl}}$ below the resting membrane potential, and others whose $E_{\mathrm{Cl}}$ is positive to resting membrane potential (Tyzio et al., 2003). This wide range of neuronal $\mathrm{Cl}^{-}$is consistent with previously published data (Tyzio et al., 2007; Berglund et al., 2008; Glykys et al., 2009) and implies that both hyperpolarizing as well as depolarizing $\mathrm{GABA}_{\mathrm{A}}$ receptor $\left(\mathrm{GABA}_{\mathrm{A}}-\mathrm{R}\right)$-mediated signaling occurs in large populations of developing neurons, via inwardly and outwardly directed $\mathrm{Cl}^{-}$fluxes.

The net effect of $\mathrm{GABA}_{\mathrm{A}}-\mathrm{R}$ activation on the frequency of spontaneous action potentials was measured in intact hippocampi prepared from neonatal (P5-P7) CLM-1 mice (Fig. 1c-e). Non-invasive extracellular recordings of MUA were performed in the CA3 pyramidal cell layer (supplemental Fig. 1, available at www. jneurosci.org as supplemental material). Bath application of the selective agonist of $\mathrm{GABA}_{\mathrm{A}}-\mathrm{R}$ isoguvacine $(10 \mu \mathrm{M}$ for $1 \mathrm{~min})$ transiently reduced spontaneous neuronal firing rate by $91.5 \pm 3.1 \%$ in 12 recordings from six intact hippocampi (Fig. $1 c-e)$, indicating that the net effect of $\mathrm{GABA}_{\mathrm{A}}-\mathrm{R}$ activation in the intact hippocampal network was inhibitory. In contrast, in the neonatal hippocampal and neocortical slice preparations, a more uniformly depolarizing $\mathrm{Cl}^{-}$equilibrium potential (Glykys et al., 2009) and a consequent excitatory action of $\mathrm{GABA}_{\mathrm{A}}-\mathrm{R}$ activation (Dzhala et al., 2005) leads to a net increase in spontaneous firing rates of neurons and an increased frequency of spontaneous population bursts in response to $\mathrm{GABA}_{\mathrm{A}}-\mathrm{R}$ agonists (Tyzio et al., 2007; Dzhala et al., 2008) .

Progressive $\left[\mathrm{Cl}^{-}\right]_{\mathrm{i}}$ accumulation and change in the action of GABA during recurrent seizures

Positive (excitatory) shifts in the reversal potential for $\mathrm{GABA}_{\mathrm{A}^{-}}$ receptor-mediated responses were observed in immature neurons after prolonged seizure activity (Khalilov et al., 2003). We considered the possibility that neuronal chloride accumulation and a consequent excitatory shift in GABA action occur and persist during recurrent seizure activity. Simultaneous highresolution two-photon fluorescence chloride imaging and extracellular field potential recordings were performed in intact hippocampi prepared from neonatal (P5-P7) CLM-1 mice (Kuner and Augustine, 2000; Berglund et al., 2008). Persistent bath application of low- $\mathrm{Mg}^{2+}$ ACSF induced recurrent interictal and ictal-like (seizure) epileptiform discharges (Fig. 2a) (for details, see Dzhala et al., 2008), which gradually increased in fre- quency (Quilichini et al., 2002, 2003; Dzhala et al., 2008) and power (Dzhala et al., 2008) (Fig. 2e-g) (see Fig. 5e,f). Starting from onset, the mean interseizure interval significantly decreased by $39 \%$ from $515.4 \pm 29.7$ to $315.7 \pm 35.6 \mathrm{~s}(n=8, p=0.0008)$ (see Fig. $5 e$ ). Over a $1 \mathrm{~h}$ period of low- $\mathrm{Mg}^{2+}$ ACSF application, the normalized mean power of recurrent ictal-like events increased by $61 \pm 24 \%(p=0.039)$ (see Fig. $5 f)$. These data are consistent with the hypothesis that neonatal seizures increase the probability of subsequent seizures.

The $\left[\mathrm{Cl}^{-}\right]_{\mathrm{i}}$ in CA3 pyramidal cells was measured between recurrent seizures as a function of the quantity $(n)$ of preceding seizures (Fig. $2 a-d$; Table 2). After one to two seizures, $35 \%$ of CA3 neurons accumulated chloride $>10 \mathrm{~mm}$ above the resting $\left[\mathrm{Cl}^{-}\right]_{\text {i. }}$ After seven to eight seizures, $71 \%$ of CA3 neurons accumulated chloride $>10 \mathrm{~mm}$ above the resting $\left[\mathrm{Cl}^{-}\right]_{\mathrm{i}}$. These changes were of sufficient magnitude to shift the $E_{\mathrm{Cl}}$ above the predicted resting membrane potential, implying a shift in GABAergic signaling from inhibitory to excitatory. Depolarized values of $E_{\mathrm{Cl}}$ in a subpopulation of CA3 neurons persisted for a long time (at least 1-2 $\mathrm{h}$ ) after cessation of recurrent seizures by perfusion of control ACSF (data not shown) and may contribute to the generation of subsequent spontaneous seizures (Khalilov et 


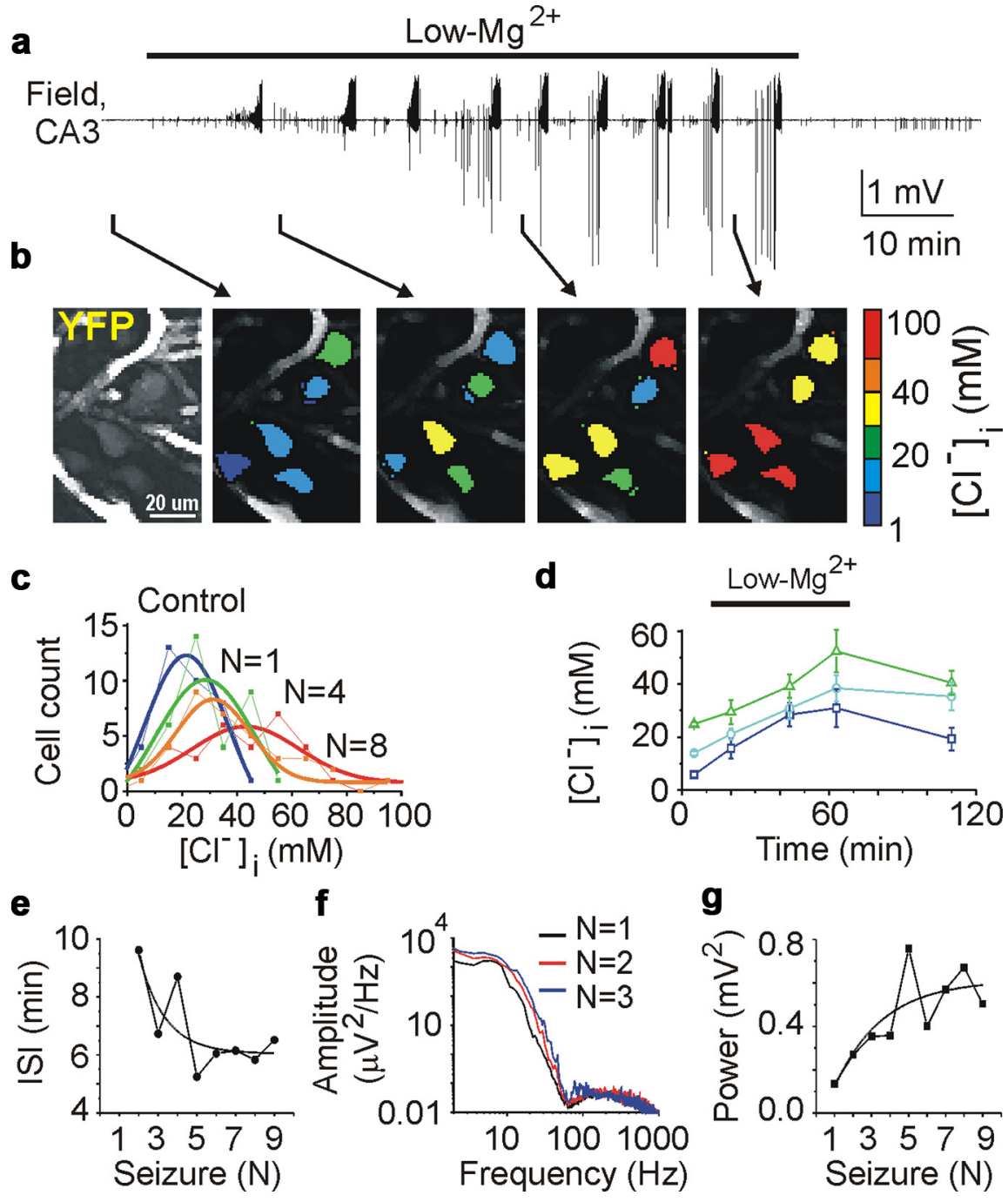

Figure 2. Neonatal seizure-induced chloride accumulation and facilitation of recurrent seizures. $\boldsymbol{a}$, Extracellular field potential recordings in the CA3 pyramidal cell layer in the intact hippocampus in vitro of the neonatal (P5) CLM-1 mouse. Recurrent seizures were induced by low-Mg ${ }^{2+} \mathrm{ACSF}$ and stopped by perfusion of control ACSF. $\boldsymbol{b}$, Effect of recurrent seizures on $\left[\mathrm{Cl}^{-}\right]_{\mathrm{i}}$. Example of two-photon confocal imaging of YFP (left) of CA3 neurons yielded pseudocolor map of $\left[\mathrm{Cl}^{-}\right]_{i}$ before seizures, after the first, fourth, and eighth recurrent seizures. c, Distribution of $\left[\mathrm{Cl}^{-}\right]_{i}$ (bin size, $10 \mathrm{~mm}$ ) in 36 identified neurons before seizures (dark blue), after one (green), four (orange), and eight (red) recurrent seizures. $\boldsymbol{d}$, Corresponding changes of mean $\left[\mathrm{Cl}^{-}\right]_{\mathrm{i}}$ in subpopulation of neurons with low $(0-10 \mathrm{~mm})$, medium $(10-20 \mathrm{~mm})$, and high $(20-30 \mathrm{~mm})$ range of control resting chloride. $\boldsymbol{e}-\boldsymbol{g}$, Seizure induced facilitation of recurrent seizures. $\boldsymbol{e}$, Interseizure intervals (ISI) decreased as a function of the number of recurrent seizures. $\boldsymbol{f}$, Power spectra of three consecutive seizures in frequency band from 1 to $1000 \mathrm{~Hz}$. g, Corresponding power of recurrent seizures as a function of the number of seizures.

al., 2003; Nardou et al., 2009). Application of low- $\mathrm{Mg}^{2+}$ ACSF in the presence of the sodium channel blocker TTX $(1 \mu \mathrm{M})$ did not alter intracellular chloride concentration $(n=3$; data not shown), suggesting that changes in $\left[\mathrm{Cl}^{-}\right]_{\mathrm{i}}$ were caused by seizure activity. Thus, recurrent seizures caused a progressive intracellular chloride accumulation as a function of the quantity of preceding seizures.

To test whether the ictal increase in $\left[\mathrm{Cl}^{-}\right]_{\mathrm{i}}$ altered the effect of $\mathrm{GABA}_{\mathrm{A}}-\mathrm{R}$ activation, we tested whether the action of the $\mathrm{GABA}_{\mathrm{A}}-\mathrm{R}$ agonist isoguvacine on neuronal activity (Fig. $1 c-e$ ) is altered by seizure activity. We tested whether isoguvacine increased or decreased multiunit activity, which allowed us to separate the effects of alterations in $E_{\mathrm{GABA}}$ (Dzhala and Staley, 2003; Ben-Ari et al., 2007) from changes in GABA release (Hirsch et al., 1999 ) and postsynaptic $\mathrm{GABA}_{\mathrm{A}}-\mathrm{R}$ conductance (Naylor et al., 2005; Goodkin et al., 2008). If GABA-mediated excitation progressively increases during the time course of spontaneous epileptiform activity, then the $\mathrm{GABA}_{\mathrm{A}}$ receptor agonist should increase the neuronal firing rate and the frequency of epileptiform discharges proportionally to the number and duration of preceding seizures. Conversely, if $\mathrm{GABA}_{\mathrm{A}}-\mathrm{R}$ function is inhibitory but limited by postsynaptic reductions in GABA conductance (Naylor et al., 2005; Goodkin et al., 2008), we would see a reduction but not a reversal in the inhibitory effects of exogenous $\mathrm{GABA}_{\mathrm{A}}-\mathrm{R}$ agonists. Finally if GABA effects were limited by presynaptic reduction in GABA release (Hirsch et al., 1999), we would see no net change in the effects of exogenous $\mathrm{GABA}_{\mathrm{A}}-\mathrm{R}$ agonists.

Interictal and ictal-like epileptiform discharges were induced by persistent bath application of low- $\mathrm{Mg}^{2+}$ ACSF in intact hippocampi prepared from neonatal (P5-P7) CLM-1 mice. Figure 3 illustrates the typical effects of isoguvacine (10 $\mu \mathrm{M}$ for $1 \mathrm{~min}$ ) on MUA and epileptiform discharges. Application of isoguvacine after the first seizure, shortly after recovery from post-ictal depression, invariably reduced MUA frequency $(n=6)$. After two to three seizures, isoguvacine transiently increased the frequency of MUA, in association with a transient increase of the frequency of interictal epileptiform discharges (IEDs). The transient excitatory action of isoguvacine was followed by a suppression of interictal and multipleunit activity (Fig. $3 a-c$ ), consistent with activity-dependent reduction in $\left[\mathrm{Cl}^{-}\right]_{\mathrm{i}}$ (Brumback and Staley, 2008). In three of six experiments, application of isoguvacine failed to block interictal activity. After four to six recurrent seizures, isoguvacine transiently increased the frequency of MUA and IEDs and often induced ictallike epileptiform discharges (six of nine applications of isoguvacine). However, this does not exclude a coincidence of the effect of isoguvacine with recurrent seizure activity (data not shown).

Thus, neonatal seizures alter polarity of the $\mathrm{GABA}_{\mathrm{A}}-\mathrm{R}$ mediated signaling and invert the net effect of $G_{A B A}-R$ activation from inhibition to transient excitation. Positive shifts in $E_{\mathrm{Cl}}$ and corresponding changes in GABA action may contribute to facilitation of recurrent seizures and resistance of recurrent seizures to GABAergic anticonvulsants.

\section{Efficacy of phenobarbital depends on the quantity of seizure activity}

The ictal shifts in $\left[\mathrm{Cl}^{-}\right]_{\mathrm{i}}$ and $E_{\mathrm{GABA}}$ can initiate a positive feedback cycle in neonatal seizures (Staley and Smith, 2001), and a depolarized value of $E_{\mathrm{GABA}}$ may contribute to the reduced efficacy of GABA-enhancing anticonvulsants (Dzhala et al., 2005, 2008). We therefore tested the effects of phenobarbital on recur- 
Table 2. $\left[\mathrm{Cl}^{-}\right]_{\mathrm{i}}$ accumulation during low-Mg ${ }^{2+}$ induced recurrent seizures

\begin{tabular}{|c|c|c|c|c|c|c|c|c|}
\hline \multirow[b]{2}{*}{ Seizures } & \multicolumn{4}{|l|}{ Control } & \multicolumn{4}{|l|}{ + Bumetanide } \\
\hline & $\Delta\left[\mathrm{Cl}^{-}\right]_{\mathrm{i}}(\mathrm{mm})$ & $n$ (cells) & IHF & $p$ & $\Delta\left[\mathrm{Cl}^{-}\right]_{\mathrm{i}}(\mathrm{mm})$ & $n$ (cells) & IHF & $p$ \\
\hline $1-2$ & $8.1 \pm 1.2$ & 187 & 4 & $<0.05$ & $6.8 \pm 0.8$ & 185 & 4 & $<0.05$ \\
\hline $3-4$ & $11.4 \pm 1.2$ & 187 & 4 & $<0.05$ & $10.4 \pm 1$ & 185 & 4 & $<0.05$ \\
\hline $5-6$ & $17.2 \pm 2.7$ & 187 & 4 & $<0.05$ & $7.5 \pm 0.75$ & 185 & 4 & $<0.05$ \\
\hline $7-8$ & $28 \pm 1.8$ & 187 & 4 & $<0.05$ & $5.2 \pm 0.85$ & 185 & 4 & $<0.05$ \\
\hline
\end{tabular}

IHF, Number of hippocampi. $p$ values correspond to one-way ANOVA, followed by Tukey's means comparison.

rent seizure activity as a function of the number of preceding seizures. Extracellular field potential recordings were performed in the CA3 pyramidal cell layer in the neonatal rat (P3-P6) wholehippocampal preparations in vitro. Bath application of low- $\mathrm{Mg}^{2+}$ ACSF induced recurrent ictal-like (seizure) epileptiform activity (Fig. 4a,d) (for details, see Dzhala et al., 2008).

The anticonvulsant efficacy of phenobarbital, measured in terms of reduction in the frequency and power of recurrent seizures, was evaluated as a function of the quantity $(n)$ of preceding seizures (Fig. $4 b-e)$. A high concentration of phenobarbital $(100 \mu \mathrm{M})$ was bath applied for 60 min. The mean frequency of seizures in the presence of phenobarbital after one preceding seizure $(n=8)$ was significantly lower than in control low- $\mathrm{Mg}^{2+}$ ACSF (Fig. 4d). After seven preceding seizures, the mean frequency of recurrent seizures in the presence of phenobarbital was $3.3 \pm 0.6$ seizures per hour $(n=7)$, not significantly different from control $(p>0.05)$ (Fig. 4d). Application of phenobarbital after one or two seizures abolished recurrent seizures in four of eight experiments (50\%) (Fig. 4e). After three to five preceding seizures, phenobarbital abolished recurrent seizures in two of seven experiments (28.6\%), and after six to eight seizures, in 1 of 11 experiments (9\%). Phenobarbital applied after one seizure depressed the power of extracellular field potential activity by $81.8 \pm 8.4 \%(n=$ $8, p=0.0036)$ of preceding control power, but phenobarbital applied after seven preceding seizures decreased power by only $45 \pm 15.3 \%(n=7, p=0.027)$ of preceding power.

Thus, neonatal seizures progressively reduce the anticonvulsant efficacy of phenobarbital. The anticonvulsant efficacy of phenobarbital was inversely proportional to the quantity of preceding seizures (Fig. 4).

\section{NKCC1 cotransporter contributes to seizure-induced chloride accumulation and the facilitation of recurrent seizures}

Immature neurons express high levels of the NKCC1 (Delpire, 2000; Wang et al., 2002; Dzhala et al., 2005) electroneutral cotransporter that imports $\mathrm{Na}^{+}, \mathrm{K}^{+}$, and $\mathrm{Cl}^{-}$. We therefore assessed the contribution of NKCC1 cotransporter to ictal $\left[\mathrm{Cl}^{-}\right]_{\mathrm{i}}$ accumulation by perfusing the NKCC1 antagonist bumetanide $(10 \mu \mathrm{M})$ after the first or second seizure induced by continuous superfusion of low- $\mathrm{Mg}^{2+} \mathrm{ACSF}$ in the intact hippocampus in vitro of the neonatal (P5-P6) CLM-1 mice (Fig. 5; Table 2). Figure $5 d$ illustrates the mean effects of recurrent seizures on intracellular chloride accumulation in control low- $\mathrm{Mg}^{2+}+\mathrm{ACSF}$ (mean \pm SE; 187 cells from $n=4$ intact hippocampi) and in the presence of bumetanide ( 185 cells from $n=4$ hippocampi). Notably, bumetanide not only reduced the mean ictal increase in $\left[\mathrm{Cl}^{-}\right]_{\mathrm{i}}$ (Fig. $5 b-d$; Table 2) but also reduced the fraction of cells that accumulated chloride $>10 \mathrm{~mm}$ above baseline chloride level in control low- $\mathrm{Mg}^{2+}$ ACSF. In the presence of bumetanide, the fraction of cells that accumulated chloride after seven to eight recurrent seizures $>10 \mathrm{~mm}$ above the baseline resting chloride level was $31 \%$ (vs $71 \%$ in control).

Additionally, bumetanide prevented the progressive increase in the power and frequency of recurrent seizures induced by low$\mathrm{Mg}^{2+}$ ACSF (Fig. 5e,f) (supplemental Figs. 2, 3, available at www. jneurosci.org as supplemental material). Over a $1 \mathrm{~h}$ period of simultaneous low- $\mathrm{Mg}^{2+}$ ACSF and bumetanide superfusion, the mean interseizure interval was not significantly different (495 \pm 59 vs $417.4 \pm 33.3 \mathrm{~s} ; n=8, p=0.36$ ) (Fig. $5 e$ ). The mean power 


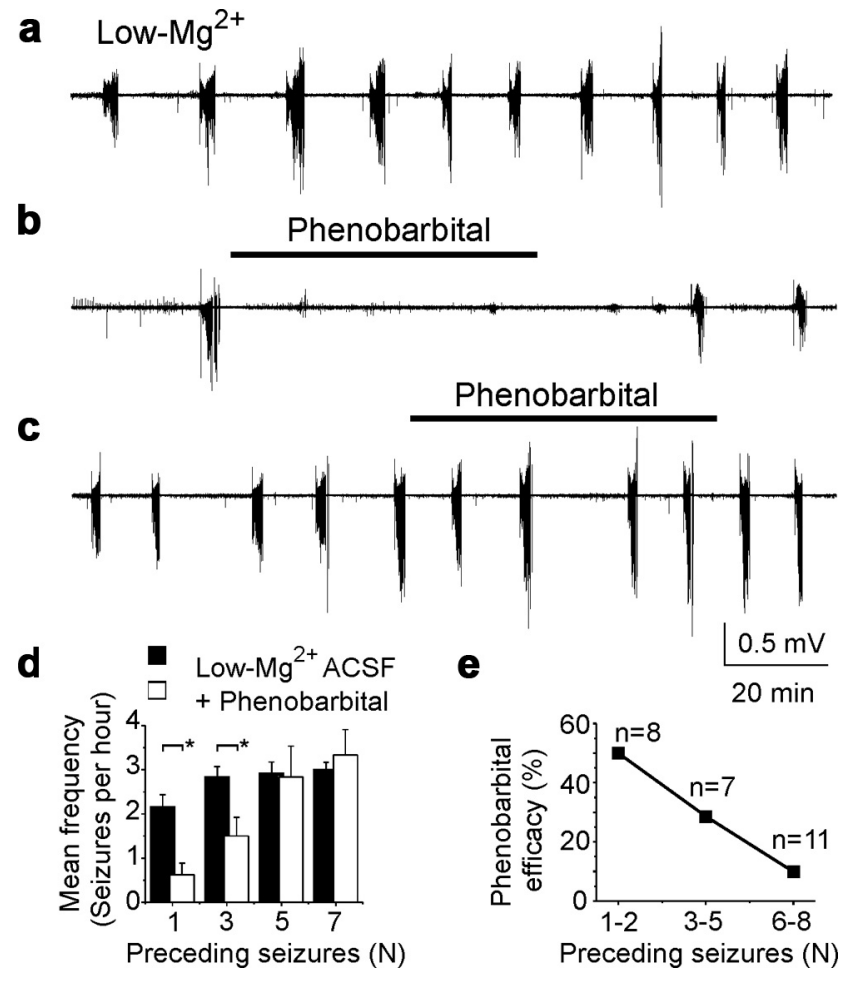

Figure 4. Seizure-dependent changes in the effects of phenobarbital on neonatal seizures. $\boldsymbol{a}$, Low-Mg ${ }^{2+}$ ACSF-induced recurrent seizures in the intact hippocampus in vitro. $\boldsymbol{b}$, Application of phenobarbital $(100 \mu \mathrm{m})$ in low-Mg ${ }^{2+}$ ACSF after one ictal-like event $(n=1)$ abolished seizures in the intact neonatal hippocampus. c, Application of phenobarbital (100 $\mu \mathrm{m})$ after five ictal-like events $(n=5)$ failed to abolish recurrent ictal-like activity in low-Mg ${ }^{2+}$ ACSF. $\boldsymbol{a}-\boldsymbol{c}$, Extracellular field potential recordings were performed in the CA3 pyramidal cell layer in the intact hippocampus in vitro of neonatal (P5-P6) rats. $\boldsymbol{d}$, Frequency of recurrent seizures as a function of preceding seizures $(n)$ in control low- $\mathrm{Mg}^{2+}$ ACSF and after application of phenobarbital. Phenobarbital applied after $n=1$ and $n=3$ seizures significantly reduced the mean frequency of recurrent seizures $\left({ }^{*} p<0.05\right)$. Phenobarbital applied after more than $n=5$ seizures failed to reduce the frequency of recurrent seizures. $\boldsymbol{e}$, Fraction of hippocampi in low$\mathrm{Mg}^{2+}$ ACSF in which seizures were abolished by $100 \mu \mathrm{m}$ phenobarbital, plotted as a function of the number of seizures before phenobarbital application. Efficacy of phenobarbital in neonatal seizures decreased as a function of quantity of previous seizure activity $(n)$.

of ictal-like events was also not significantly different (105 $\pm 22 \%$ of control, $p=0.8$ ) (Fig. $5 f$ ).

We tested also whether NKCC1 block prevented excitatory shift in the action of GABA induced by recurrent seizures (Fig. 3). Figure 6 illustrates the typical effects of isoguvacine $(10 \mu \mathrm{M}$ for 1 min) on MUA and epileptiform discharges in the presence of bumetanide. Application of isoguvacine after the first seizure $(n=1)$, shortly after recovery from post-ictal depression, transiently reduced MUA frequency by $87 \pm 4 \%$ (eight recordings in $n=4$ hippocampi). Inhibitory action of isoguvacine persisted also after two to three as well as after four to five recurrent seizures (Fig. 6). After two to three seizures, isoguvacine application did not induce epileptiform discharges and transiently reduced the frequency of MUA by $83.5 \pm 4 \%$ (eight recordings in $n=4$ hippocampi). After four to six recurrent seizures, isoguvacine transiently reduced the frequency of MUA by $74.6 \pm 6.2 \%$ (eight recordings in $n=4$ hippocampi). In one of four experiments, recurrent seizures $(n=6)$ were followed by persistent interictallike epileptiform discharges. Application of isoguvacine transiently abolished these epileptiform discharges (data not shown).

Thus, the diuretic bumetanide prevented or reduced seizureinduced progressive $\left[\mathrm{Cl}^{-}\right]_{\mathrm{i}}$ accumulation in large subpopula- tions of neurons (Fig. $5 c$; Table 2), prevented changes in the action of GABA (Fig. 6), and reduced seizure-dependent facilitation of recurrent seizures (Fig. 5e,f) (supplemental Figs. 2, 3, available at www.jneurosci.org as supplemental material).

\section{Potential mechanism of increased NKCC1 activity during recurrent seizures}

NKCC1 is an electroneutral bidirectional transporter that can perform net $\mathrm{Na}^{+}, \mathrm{K}^{+}$, and $2 \mathrm{Cl}^{-}$ion influx or efflux, depending on the concentration gradients of the transported ions (Payne, 1997; Gamba, 2005; Brumback and Staley, 2008). The activation of NKCC1 requires phosphorylation of Thr-212 and Thr-217 in the cytoplasmic N terminus (Darman and Forbush, 2002; Flemmer et al., 2002; Payne et al., 2003). We monitored the phosphorylation of NKCC1 at these sites with anti-R5, an antibody that specifically recognizes phosphorylation of Thr-212 and Thr-217 in vitro and in vivo (Darman and Forbush, 2002; Flemmer et al., 2002; Gimenez and Forbush, 2003). Western blotting detected phospho-NKCC1 in both control and seizure conditions (supplemental Fig. 4, available at www.jneurosci.org as supplemental material). These findings indicate that NKCC1 is present, phosphorylated, and presumably active in hippocampi from neonatal mice with recurrent seizures, but they do not provide evidence that increased seizure activity is associated with increased phosphorylation of NKCC1 at its known regulatory sites.

Recurrent seizures in neonatal and adult cortical structures have long been known to cause acute, activity-dependent alterations in neuronal ion concentrations (Moody et al., 1974; Heinemann et al., 1977; Khalilov et al., 1999b; Xiong and Stringer, 2000). In the intact neonatal hippocampal formation, recurrent ictal-like epileptiform discharges increase extracellular concentration of $\mathrm{K}^{+}\left(\left[\mathrm{K}^{+}\right]_{\mathrm{o}}\right)$ to $12.5 \mathrm{~mm}$ (Khalilov et al., 1999b). Ictal accumulation of extracellular potassium will increase the $\left[\mathrm{Cl}^{-}\right]_{\mathrm{i}}$ at which NKCC1 transport reaches equilibrium (Brumback and Staley, 2008). We therefore assessed the contribution of NKCC1mediated cotransport to intracellular chloride accumulation as a function of extracellular concentration of $\mathrm{K}^{+}$(Fig. $7 a-e$ ). In the presence of the sodium channel blocker TTX ( $1 \mu \mathrm{M})$, increasing $\left[\mathrm{K}^{+}\right]_{\mathrm{o}}$ from 3.5 (control) to $8.5 \mathrm{~mm}$ resulted in a corresponding increase in $\left[\mathrm{Cl}^{-}\right]_{\mathrm{i}}$ from $19.9 \pm 0.8$ to $26.9 \pm 1.2 \mathrm{mM}(p<0.05 \mathrm{vs}$ baseline $\left[\mathrm{Cl}^{-}\right]_{\mathrm{i}}$, ANOVA followed by Tukey's means comparison test; $n=138$ cells in 4 hippocampi) (Fig. $7 e$ ). Increasing $\left[\mathrm{K}^{+}\right]_{\mathrm{o}}$ to $13.5 \mathrm{~mm}$ increased $\left[\mathrm{Cl}^{-}\right]_{\mathrm{i}}$ to $45.6 \pm 2 \mathrm{mM}(p<0.05)$. In the presence of bumetanide $(10 \mu \mathrm{M})$, increasing $\left[\mathrm{K}^{+}\right]_{\mathrm{o}}$ from 3.5 to $8.5 \mathrm{~mm}$ resulted in a corresponding increase in $\left[\mathrm{Cl}^{-}\right]_{\mathrm{i}}$ from $17.4 \pm 0.9$ to $18.4 \pm 1 \mathrm{~mm} ; p=0.43, n=132$ cells in 4 hippocampi (Fig. $7 e$ ). Increasing $\left[\mathrm{K}^{+}\right]_{\mathrm{o}}$ to $13.5 \mathrm{~mm}$ increased $\left[\mathrm{Cl}^{-}\right]_{\mathrm{i}}$ to $21.8 \pm 1 \mathrm{mM}(p=0.02)$. However, this increase in the presence of bumetanide was $23.8 \mathrm{~mm}$ lower than in control conditions $(21.8 \pm 1$ vs $45.6 \pm 2 \mathrm{~mm} ; p<0.05)$ (Fig. $7 e$ ). Thus, seizureinduced $\left[\mathrm{K}^{+}\right]_{\mathrm{o}}$ elevation is sufficient to increase $\left[\mathrm{Cl}^{-}\right]_{\mathrm{i}}$ accumulation via NKCC1 cotransport, resulting in alterations of $E_{\mathrm{GABA}}$ during recurrent seizures (Figs. 2, 3, 5, 6).

\section{NMDA receptor, NKCC1 activity, and inverted action of GABA}

The NKCC1 phosphorylation data and $\left[\mathrm{K}^{+}\right]_{\mathrm{o}}$ data suggest that at least some aspects of ictal changes in $\left[\mathrm{Cl}^{-}\right]_{\mathrm{i}}$ may be independent of calcium-dependent signal transduction mechanisms. Conversely, epileptogenic transformation of the intact hippocampal neuronal network required voltage-dependent activation of NMDA receptors (NMDA-Rs) and long-term alterations in GABAergic synapses, which became excitatory because of a pos- 
itive shift in the chloride reversal potential (Khalilov et al., 2003). We therefore determined the contribution of NMDA-R to seizure-induced changes in the net effect of $\mathrm{GABA}_{\mathrm{A}}$ receptor activation and corresponding alterations of recurrent seizures (Figs. 2, 3, 5). Because seizures are NMDA-R dependent in the low- $\mathrm{Mg}^{2+}$ model, we used the kainic acid model of epileptiform activities in the intact neonatal hippocampus in vitro of the neonatal (P5-P6) mice (Prince et al., 1973; Fisher et al., 1976; Khalilov et al., 1999b).

In control ACSF, transient application of kainic acid ( $1 \mu \mathrm{M}$ for $4-5 \mathrm{~min}$ ) progressively increased the frequency of MUA and induced interictal and ictal-like epileptiform discharges, followed by a postictal depression (eight recordings in $n=4$ hippocampi) (Fig. 8a). Repeated applications of kainic acid (five applications at 15 min intervals) induced inter-ictal and ictal-like epileptiform discharges that progressively increased in amplitude and power (Fig. 8d). After five applications of kainic acid, spontaneous recurrent epileptiform discharges were generated in three of four intact hippocampi. Brief applications of isoguvacine (10 $\mu \mathrm{M}$ for $1 \mathrm{~min}$ ) transiently increased the frequency of spontaneous epileptiform discharges by $225 \pm 154 \%(p=0.04$; six applications in $n=3$ hippocampi) (Fig. $8 a, e$ ), suggesting seizure-induced changes in the action of GABA and contribution of the excitatory action of GABA to generation of spontaneous recurrent epileptiform discharges.

We determined whether the noncompetitive NMDA-R antagonist MK801 [(+)5-methyl-10,11-dihydro-5H-dibenzo [a,d] cyclohepten-5,10-imine maleate] prevented seizure-induced changes in the net effect of $\mathrm{GABA}_{\mathrm{A}}$ - $\mathrm{R}$ activation from inhibition to excitation assayed by the frequency of spontaneous action potentials and/or interictal epileptiform discharges (Fig. $8 b, e)$. In the presence of MK801 (20 $\mu \mathrm{M})$, transient applications of kainic acid induced interictal and ictal-like epileptiform discharges that progressively decreased in amplitude and power (six recordings in $n=3$ hippocampi) (Fig. $8 d$ ). Persistent perfusion of MK801 did not prevent generation of spontaneous epileptiform discharges induced by repeated applications of kainic acid. Brief applications of isoguvacine (10 $\mu \mathrm{M}$ for $1 \mathrm{~min})$ in the presence of MK801 transiently increased the frequency of spontaneous epileptiform discharges by $368 \pm 129 \%$ ( $p=0.015$; six applications in $n=3$ hippocampi) (Fig. $8 b, e$ ) before depressing them. These effects are similar to what was seen in control conditions (Fig. 2), suggesting that NMDA-Rs did not contribute to seizure-induced chloride accumulation and the corresponding changes in the action of GABA.

As in control conditions, the NKCC1 antagonist bumetanide $(10 \mu \mathrm{M})$ prevented the seizure-induced excitatory shift

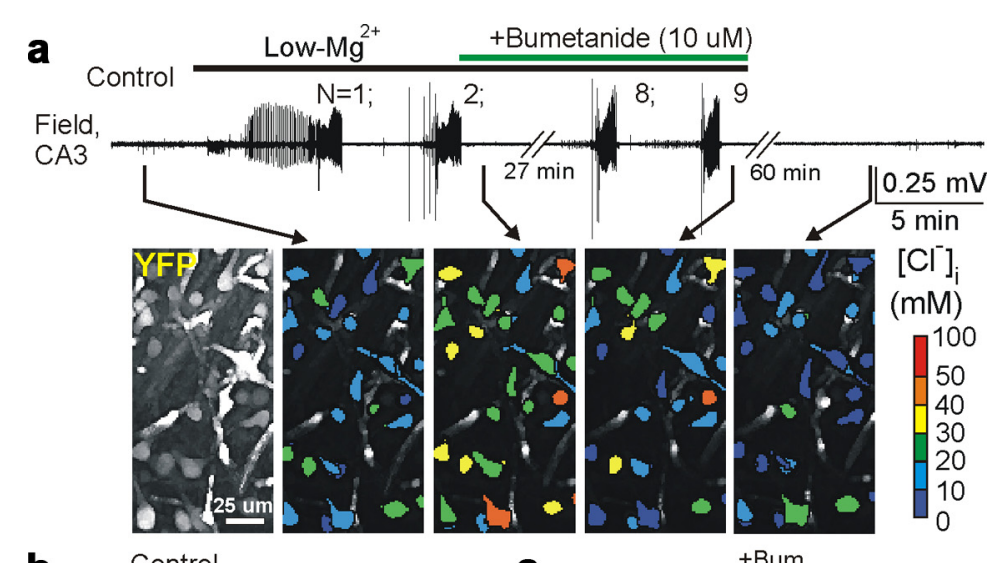

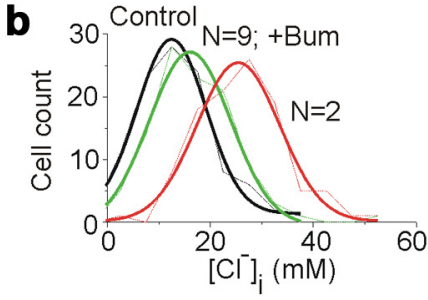
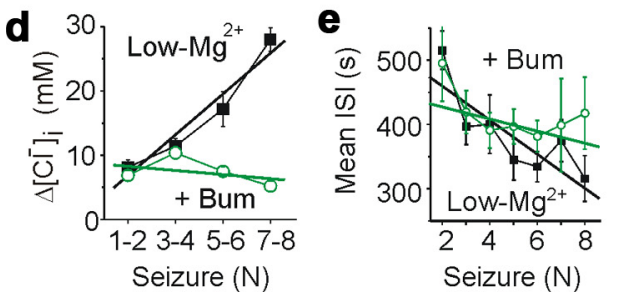

C
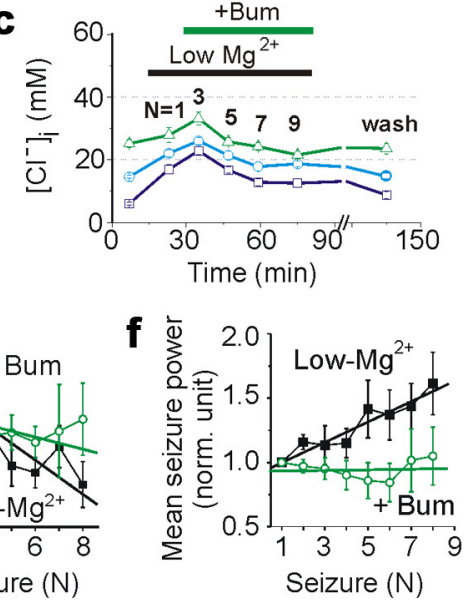

Figure 5. The role of NKCC 1 in seizure-induced chloride accumulation and facilitation of recurrent seizures. $\boldsymbol{a}, \mathrm{Top}, \mathrm{Low}-\mathrm{Mg}{ }^{2+}$ ACSF induced recurrent seizures in control and in the presence of NKCC1 blocker bumetanide (10 $\mu \mathrm{M})$. Extracellular field potential collings in the CA3 pyramidal cell layer in the intact hippocampus in vitro of neonatal (P5) CLM-1 mouse. Bottom, Example of 列 . $1 \mathrm{~mm}$ after $n=9$ seizures. $c$, Seizure-induced changes of mean $\left[\mathrm{Cl}^{-}\right]_{\mathrm{i}}$ in subpopulation of neurons with low $(0-10 \mathrm{~mm})$ (10-20 mm), and high (20-30 mm) range of control resting chloride. Bumetanide prevented seizure-induced neuronal presence of bumetanide. Solid lines represent linear regression [Control; low-Mg ${ }^{2+}$ ACSF (black): $r=0.97 \pm 1.66 ; p=0.03$ metanide (green): $r=-0.43 \pm 2.6 ; p=0.57]$. In low-Mg ${ }^{2+} \mathrm{ACSF}_{\mathrm{C}}\left[\mathrm{Cl}^{-}\right]_{\mathrm{i}}$ progressively increases as a function of recurrent $0.2) . f$, Corresponding linear regression fit of normalized mean power in control (black; $r=0.95 \pm 0.07 ; p=$ $0.0003 ; n=8$ ) and in the presence of bumetanide (green; $r=0.08 \pm 0.08 ; p=0.85 ; n=8$ ). Bumetanide prevents a progressive increase of seizure power and frequency.

in the action of GABA $(n=3)$ (Fig. $8 c, e)$ in the presence of MK801 $(20 \mu \mathrm{M})$. In the presence of MK801 and bumetanide, repeated applications of kainic acid (five applications for 5 min each; 15 min intervals) induced interictal and ictal-like epileptiform discharges that progressively decreased in power and amplitude (Fig. 8c,d). Spontaneous epileptiform discharges after five applications of kainic acid were recorded in one of three experiments (33.3\%). Brief applications of isoguvacine (10 $\mu \mathrm{M}$ for $1 \mathrm{~min}$ ) abolished spontaneous epileptiform discharges (two recordings in $n=1$ hippocampus) and/or reduced the frequency of MUA (six recordings in $n=3$ hippocampi). Thus, seizure-induced NKCC1-dependent chloride accumulation and the excitatory shift in the action of GABA was NMDA-receptor independent. 


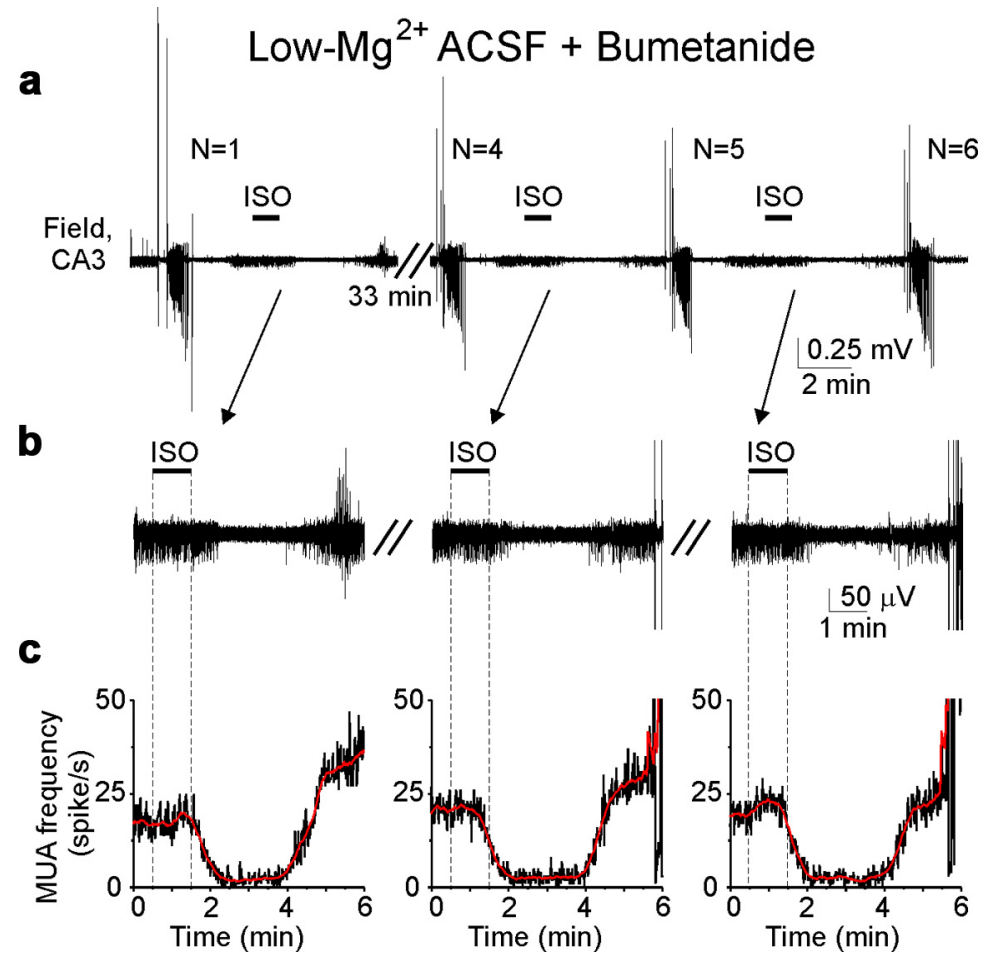

Figure 6. The role of NKCC 1 in seizure-induced changes in the action of GABA. $\boldsymbol{a}, \boldsymbol{b}$, Extracellular field potential recordings in the CA3 pyramidal cell layer in the intact hippocampus in vitro of the neonatal (P5) mouse. Recurrent seizures were induced by low-Mg ${ }^{2+}$ ACSF in the presence of NKCC1 blocker bumetanide (10 $\mu \mathrm{m}$ ). Applications of isoguvacine (ISO; $10 \mu \mathrm{m}$ for $1 \mathrm{~min}$ ) after seizure and recovery from post-ictal depression transiently decreased neuronal firing rate. $c$, Corresponding frequency of MUA. Vertical dashed lines delineate isoguvacine application. Red lines represent adjacent averaging of 20 data points. Bumetanide prevented seizure-induced changes in the effects of the $G_{A B A}$-R agonist isoguvacine on MUA and epileptiform discharges (Fig. 3).

\section{Long-term pro-convulsive effect of $\mathrm{GABA}_{\mathrm{A}}$ receptor antagonist}

The pro-convulsive effect of complete blockade of $\mathrm{GABA}_{\mathrm{A}}-\mathrm{R}$ indicates that, at $\mathrm{P} 4-\mathrm{P} 6, \mathrm{GABA}_{\mathrm{A}}$ receptors subserve a significant inhibitory function (Khalilov et al., 1999a; Wells et al., 2000). In those studies, the $\mathrm{GABA}_{\mathrm{A}}-\mathrm{R}$ antagonists bicuculline and picrotoxin induced glutamate-receptor-mediated interictal and ictallike activities in the intact hippocampus. We determined the long-term effect of $\mathrm{GABA}_{\mathrm{A}}$ - R antagonist SR 95531 (gabazine) on spontaneous neuronal activity. We performed non-invasive extracellular field potential recordings of synchronous population activity and MUA in the CA3 pyramidal cell layer in the intact hippocampal preparations from P4-P6 rats (supplemental Fig. 1, available at www.jneurosci.org as supplemental material). In control ACSF, bath application of SR 95531 (10 $\mu \mathrm{M}$ for 3-4 min) progressively increased the frequency of MUA by $44 \pm 13.2 \%$ from $13.5 \pm 1.7$ to $19.3 \pm 2.8$ spikes $/ \mathrm{s}(p=0.004 ; n=14$ recordings in 8 hippocampi) (data not shown) and rapidly, within 2-3 min, induced interictal and ictal-like epileptiform discharges, followed by a post-ictal depression with reduced neuronal activity (Fig. 9a). After removal of the drug and shortly after post-ictal depression, recurrent interictal and tonic-clonic epileptiform discharges occurred in all intact hippocampi for an extended period of 30-60 $\min$ (mean, $42.8 \pm 2.8 \min$ for $n=16$ hippocampi at P4-P5). Spontaneous epileptiform discharges, in some experiments, persisted for several hours in drug-free ACSF (data not shown), suggesting that their persistence was not related to residual antagonist but rather attributable to activitydependent long-term changes in synaptic plasticity (Schneiderman et al., 1994; Bains et al., 1999; Abegg et al., 2004; Arnold et al.,
2005). We considered the possibility that spontaneous epileptiform discharges induced by $\mathrm{GABA}_{\mathrm{A}}-\mathrm{R}$ blockade were as effective as low- $\mathrm{Mg}^{2+}$-induced activity in inducing the shift in neuronal $\left[\mathrm{Cl}^{-}\right]_{\mathrm{i}}$ and the net action of $\mathrm{GABA}_{\mathrm{A}}-\mathrm{R}$ activation.

\section{Recurrent seizures cause progressive NKCC1-dependent change in the action of GABA}

In control conditions, brief bath application of isoguvacine (10 $\mu \mathrm{M}$ for $1 \mathrm{~min}$ ) transiently reduced the frequency of MUA by $63.4 \pm 5.7 \%(p=0.0009 ; n=6)$ (Fig. $9 b, d, e)$. Spontaneous interictal and ictal-like epileptiform discharges were then induced by transient application of the $\mathrm{GABA}_{\mathrm{A}}-\mathrm{R}$ antagonist SR 95531 (10 $\mu \mathrm{M}$ for $3 \mathrm{~min}$ ) (Fig. $9 a$ ). At $30 \mathrm{~min}$ after onset of spontaneous epileptiform discharges, bath application of isoguvacine transiently increased the frequency of multiple-unit activity frequency by $60.3 \pm$ $22.1 \%(p=0.007 ; n=6)$, in association with a transient increase of the frequency of IEDs (Fig. 9b,d). Subsequently, MUA frequency decreased, consistent with activity-dependent reduction in $\left[\mathrm{Cl}^{-}\right]_{\mathrm{i}}$ (Brumback and Staley, 2008). At 60-70 min after onset of spontaneous seizures, isoguvacine transiently increased the frequency of MUA by $59.3 \pm 22 \%(p=0.015)$, in association with transiently induced IEDs, followed by a decrease as seen at $30 \mathrm{~min}$. The biphasic action of isoguvacine persisted at least for $1-2 \mathrm{~h}$ after termination of spontaneous epileptiform discharges.

In the presence of bumetanide, application of isoguvacine (10 $\mu \mathrm{M}$ for $1 \mathrm{~min}$ ) transiently reduced the frequency of MUA by $82.7 \pm 4.2 \%(p=0.0004 ; n=6)$ (Fig. $9 c-e)$. At $30 \mathrm{~min}$ after onset of spontaneous epileptiform discharges induced by SR 95531, isoguvacine reduced MUA frequency by $44.3 \pm 14.4 \%$ $(p=0.015 ; n=6)$ and did not induce epileptiform discharges or increase the frequency of epileptiform discharges (Fig. $9 c, d$ ). At 60-70 min after onset of spontaneous epileptiform discharges, isoguvacine invariably diminished MUA frequency by $50.7 \pm$ $16.3 \%(p=0.002 ; n=6)$. Thus, the diuretic bumetanide prevents or reduces seizure-induced changes in the action of GABA during spontaneous seizures and after termination of seizures. In summary, although these data do not exclude presynaptic or postsynaptic alterations in GABA conductance, they demonstrate a clear reversal of the effect of $\mathrm{GABA}_{\mathrm{A}}-\mathrm{R}$ activation that is NKCC1 dependent, and independent of the mechanism of seizure induction. These data support the idea that NKCC1 activity underlies the post-ictal increase in $\left[\mathrm{Cl}^{-}\right]_{\mathrm{i}}$ (Figs. 2, 5) and the excitatory effects of GABA.

\section{NKCC1-dependent changes contribute to the time course of spontaneous seizures}

To determine whether the seizure-induced, NKCC1-dependent changes in $\mathrm{GABA}_{\mathrm{A}}-\mathrm{R}$ function contribute to the increased probability of subsequent seizures (Dzhala and Staley, 2003; Khazipov et al., 2004; Dzhala et al., 2005, 2008), we assessed the effects of NKCC1 cotransporter blocker bumetanide on the time course of 
spontaneous seizures assayed by the quantity, duration, and power of spontaneous epileptiform activity in the P3-P5 intact hippocampal preparations (supplemental Fig. 5a-e, available at www.jneurosci.org as supplemental material). In control ACSF, brief application of SR $95531(10 \mu \mathrm{M})$ induced spontaneous seizures in 16 of 18 preparations. The duration of this status epilepticus was $41.7 \pm 2.5 \min (n=16)$. In the presence of bumetanide, similarly brief application of SR 95531 induced a shorter period of spontaneous interictal and ictallike discharges $(31.3 \pm 2.2 \mathrm{~min} ; p=0.004)$ (supplemental Fig. $5 c$, available at www. jneurosci.org as supplemental material) in 10 of 15 preparations. The number of spontaneous ictal-like episodes induced by $\mathrm{GABA}_{\mathrm{A}}-\mathrm{R}$ block was not significantly different: $2.1 \pm 0.3$ seizures in SR 95531 and $1.8 \pm 0.3$ seizures in the presence of SR 95531 + bumetanide ( $p=0.7$ ) (supplemental Fig. $5 c$, available at www.jneurosci. org as supplemental material). We also assessed the power of SR 95531-induced epileptiform activity in control ACSF and in the presence of bumetanide (supplemental Fig. 5d,e, available at www.jneurosci. org as supplemental material). The effect of bumetanide on EEG power was relatively low shortly after washout of $\mathrm{GABA}_{\mathrm{A}}-\mathrm{R}$ antagonists $(\sim 10 \%)$ but gradually increased to $\sim 45 \%$ by the end of the seizure activity induced by transient exposure to SR 95531. Although these data support a progressive, seizure-induced increase in $\left[\mathrm{Cl}^{-}\right]_{\mathrm{i}}$ and excitatory shift in $\mathrm{GABA}_{\mathrm{A}}-\mathrm{R}$ function, the alternative possibility was that SR 95531 was incompletely washed out early, in which case the impact of bumetanide on NKCC1 would initially be minimized as a result of reduced $\mathrm{GABA}_{\mathrm{A}}$-receptor-mediated chloride conductance. This was unlikely because we had already seen a stable impact of $\mathrm{GABA}_{\mathrm{A}}-\mathrm{R}$ agonist application (Fig. $9 d$ ) at different time points after washout of SR 95531 during and after spontaneous seizures. We conclude that neonatal seizures increase the probability of recurrent neonatal seizures via NKCC1-dependent chloride accumulation and consequent alteration in GABA actions.

\section{Neonatal seizures change the polarity of synaptic $\mathrm{GABA}_{\mathrm{A}}$ responses}

To further characterize the mechanisms of seizure-induced alterations in $\left[\mathrm{Cl}^{-}\right]_{\mathrm{i}}$, GABA actions, and seizure activity, we assessed the effects of endogenously released GABA on neuronal firing rate and epileptiform activity and as a function of the number of seizures.

The net effect of $\mathrm{GABA}_{\mathrm{A}}-\mathrm{R}$ activation may be inhibitory even when $E_{\mathrm{GABA}}$ is positive to resting membrane potential. Large $\mathrm{GABA}_{\mathrm{A}}-\mathrm{R}$-mediated anion conductance effectively reduces the input membrane resistance and thereby shunts excitatory glutamatergic inputs, resulting in suppression of neuronal activity (Qian and Sejnowski, 1990; Staley and Mody, 1992; Khalilov et al., 1999a). We determined whether the inhibitory operation of $\mathrm{GABA}_{\mathrm{A}}-\mathrm{R}$ in the intact hippocampal network was mediated by synaptic inhibitory mechanism and whether neonatal seizures alter this inhibition. Pharmacological protocols were used to de-
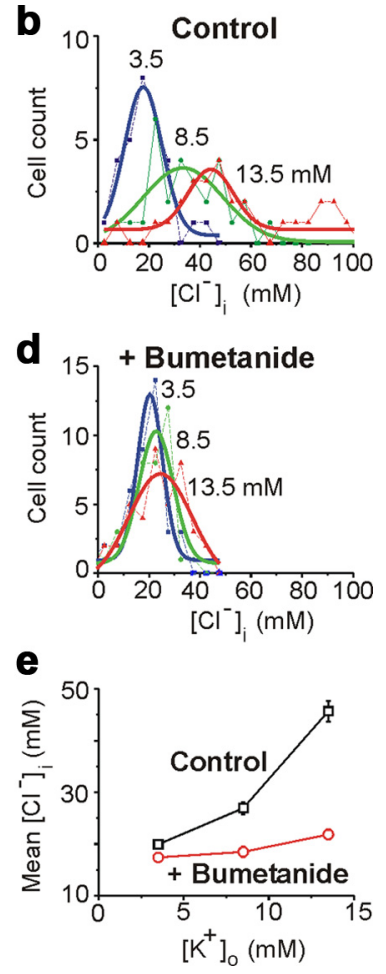

Control

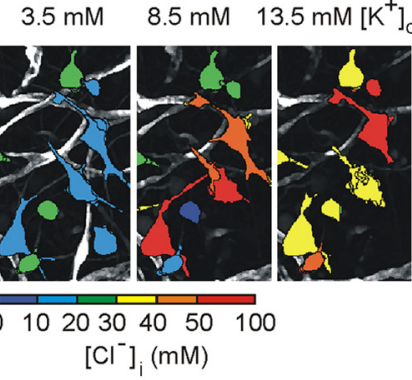

+ Bumetanide

$3.5 \mathrm{mM} \quad 8.5 \mathrm{mM} \quad 13.5 \mathrm{mM}\left[\mathrm{K}^{+}\right]$

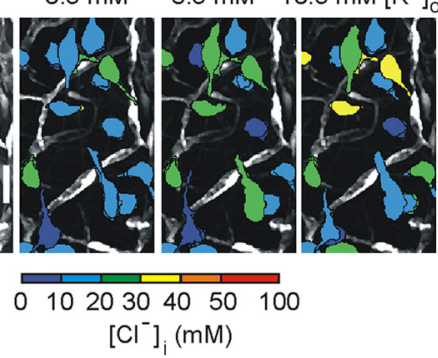

Figure 7. Concentration gradient of potassium regulates NKCC1 activity. $\boldsymbol{a}-\boldsymbol{e}$, Changes in intracellular chloride distribution as a function of $\left[\mathrm{K}^{+}\right]_{0}$ in the presence of the sodium channel blocker TTX $(1 \mu \mathrm{M}) . \boldsymbol{a}, \boldsymbol{c}$, Examples of two-photon confocal imaging of and in the presence of bumetanide (d, $n=40$ identified neurons). function of $\left[\mathrm{K}^{+}\right]_{0}$ in control and in the presence of bumetanide.

termine the contributions of intrinsic and synaptic activities to the generation of neuronal discharges and estimate the degree to which endogenous synaptic activity altered spontaneous neuronal firing rate in population of neurons (Cohen and Miles, 2000; Dzhala and Staley, 2003). In control conditions, bath application of the AMPA and NMDA receptor antagonists kynurenic acid (2 $\mathrm{mM}$ ) and the metabotropic $\mathrm{GABA}_{\mathrm{B}}$ receptor antagonist CGP $55845(1 \mu \mathrm{M})$ significantly reduced neuronal firing rate by $32.5 \%$, from $12.3 \pm 1.3$ to $8.3 \pm 0.8$ spikes $/ \mathrm{s}(n=14 ; p=0.0002$, paired $t$ test) (Fig. 10a). Subsequent application of the selective, competitive $\mathrm{GABA}_{\mathrm{A}}-\mathrm{R}$ antagonist SR $95531(10 \mu \mathrm{M})$, in the presence of KYNA and CGP 55845, increased neuronal firing rate in 10 of 14 recordings and did not significantly change neuronal firing rate in the remaining four recordings (Fig. 10a). The average mean frequency of neuronal discharges under these conditions increased by $21 \%$ from $8.3 \pm 0.8$ to $10.04 \pm 0.9$ spikes/s $(p=0.009)$. These findings are consistent with the pro-convulsive effect of $\mathrm{GABA}_{\mathrm{A}}-\mathrm{R}$ antagonists in the intact hippocampal preparation (Khalilov et al., 1999a) and indicate a net inhibitory action of endogenously released GABA in the intact CA3 hippocampal network at this early postnatal age (P3-P5).

To determine whether the action of endogenously released GABA is altered by previous seizure activity, we measured the impact of $\mathrm{GABA}_{\mathrm{A}}-\mathrm{R}$ block on the rate of spontaneous action potentials as a function of the number of preceding seizures in the CA3 pyramidal cell layer of the intact neonatal (P3-P5) hippocampus. Spontaneous seizures were induced by brief application of SR 95531 (10 $\mu \mathrm{M}$ for 3-4 min). At 30-40 min after onset of spontaneous epileptiform discharges, bath application of KYNA (2 mM for $10 \mathrm{~min}$ ) in combination with CGP 55845 ( $1 \mu \mathrm{M}$ ) 


\section{a Control}

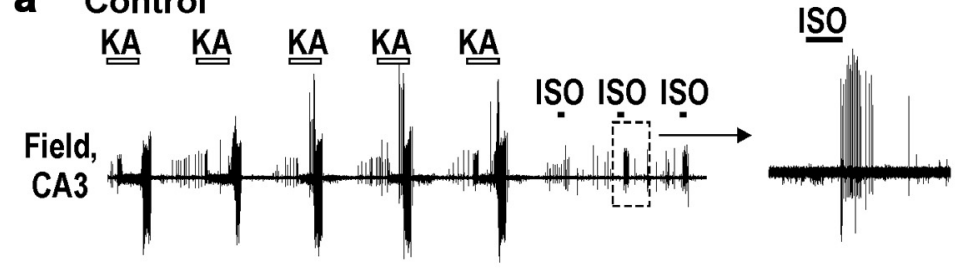

b + MK801

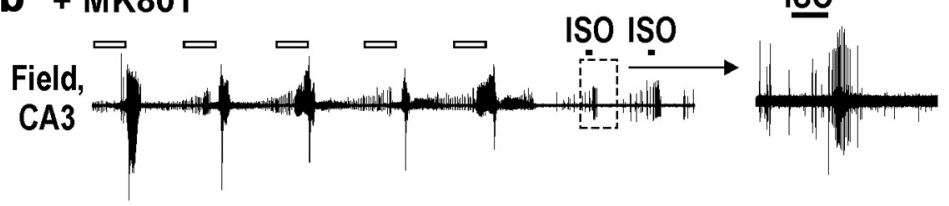

C + MK801 \& Bumetanide

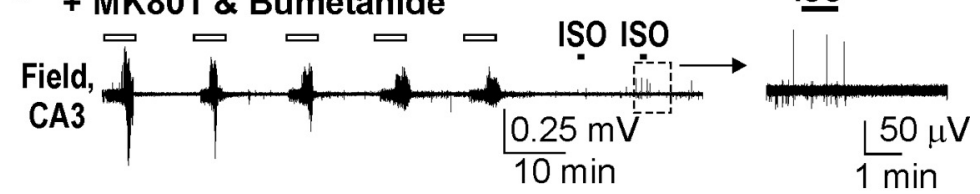

d
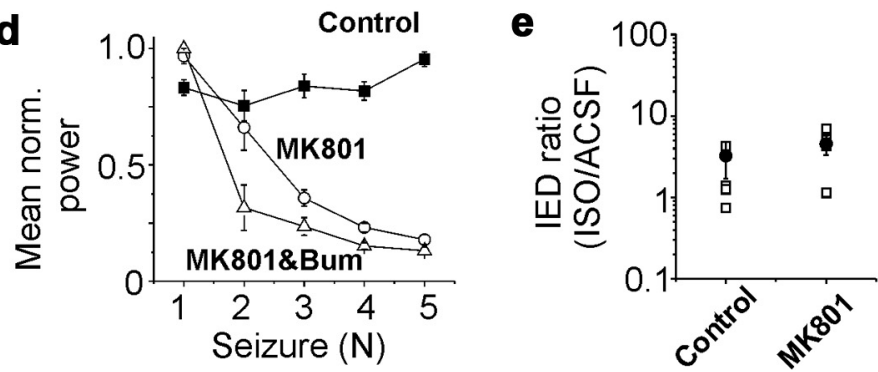

Figure 8. Seizure-induced changes in the action of GABA are NMDA receptor independent. $\boldsymbol{a}$, Repetitive applications of kainic acid (KA; $1 \mu \mathrm{m}$ for $5 \mathrm{~min}$; open bars) induced ictal-like epileptiform discharges (seizures) followed by spontaneous IEDs. Brief applications of isoguvacine (ISO; $10 \mu \mathrm{m}$ for $1 \mathrm{~min}$; filled bars) transiently increased the frequency of IEDs. $\boldsymbol{b}$, Perfusion of the noncompetitive NMDA receptor antagonist MK801 $(20 \mu \mathrm{M})$ depressed KA-induced seizures. Applications of isoguvacine increased the frequency of spontaneous IEDs. c, Simultaneous perfusion of MK801 and bumetanide $(10 \mu \mathrm{M})$ strongly depressed kainic acid-induced seizures and prevented excitatory shift in the action of GABA. Applications of isoguvacine reduced the frequency of MUA and/or IEDs. $\boldsymbol{a}-\boldsymbol{c}$, Extracellular field potential recordings in the CA3 pyramidal cell layer in the intact hippocampus of neonatal (P5-P6) mice. $\boldsymbol{d}$, Normalized power of KA-induced seizures (mean \pm SE) in control (squares), in the presence of MK801 (circles), and both MK801 and bumetanide (Bum; triangles). $\boldsymbol{e}$, Effects of isoguvacine on the frequency of spontaneous IEDs. inhibition. This could be attributable to a number of factors, including long-term potentiation of glutamatergic synapses between pyramidal cells induced by epileptiform activity (Ben-Ari and Gho, 1988; Bains et al., 1999), as evidenced by the increased impact of KYNA on MUA during status epilepticus. However, glutamatergic mechanisms do not explain the alterations in MUA observed in the presence of KYNA. The loss of inhibitory effect of endogenously released GABA could arise from (1) a positive shift in the chloride equilibrium potential in a large population of cells (Khalilov et al., 2003), (2) a presynaptic reduction in GABA release (Hirsch et al., 1999), or (3) a reduction in the postsynaptic $\mathrm{GABA}_{\mathrm{A}}$ conductance (Naylor et al., 2005). However, other than a long-term shift in $E_{\mathrm{GABA}}$, none of these effects explain the post-ictal reduction in MUA frequency when $\mathrm{GABA}_{\mathrm{A}}$-Rs were blocked.

\section{Cell-specific actions of GABA on intracellular $\mathrm{Ca}^{2+}$ influx}

The heterogeneity of neuronal $\left[\mathrm{Cl}^{-}\right]_{\mathrm{i}}$ (Fig. 1) and the post-ictal effects of endogenously released GABA in the preceding experiments raise the possibility that subpopulations of neurons may have distinct responses to GABA, either excitatory or inhibitory, and the MUA assay was measuring the network-wide average of those distinct responses. To analyze the response to GABA at the level of individual neurons, the action of GABA was assayed by changes in intracellular calcium (Stosiek et al., 2003). Large populations of $\mathrm{CA} 3$ neurons in the intact neonatal (P4abolished epileptiform discharges and reduced the neuronal firing rate by $50 \%$, from $10.3 \pm 2.3$ to $5.3 \pm 1.8$ spikes $/ \mathrm{s}(n=$ $14 ; p=0.002$ ) (Fig. 10b). Subsequent application of the $\mathrm{GABA}_{\mathrm{A}}-\mathrm{R}$ antagonist SR 95531, in the presence of KYNA and CGP 55845, induced three types of responses on MUA frequency: (1) significantly increased MUA frequency in 3 of 14 total recordings, (2) unchanged MUA frequency in six recordings, and (3) significantly decreased MUA frequency in the remaining five recordings (Fig. 10b). The absence of an effect of SR 95531 on action potential frequency in the majority of recordings indicates that the net effect of GABA is no longer inhibitory after neonatal seizures. We also assessed the effect of endogenous GABA on neuronal firing rates as a function of the number of spontaneous seizures (Fig. 10c). We found a linear correlation between the number of spontaneous seizures and the action of GABA on neuronal firing rates. After one to two spontaneous seizures, the $\mathrm{GABA}_{\mathrm{A}}-\mathrm{R}$ antagonist SR 95531, when AMPA and NMDA receptors were blocked, did not significantly change the neuronal firing rate $(112 \pm 9.9 \% ; p=0.38)$. After three to four spontaneous seizures, SR 95531 diminished neuronal firing rate to $76 \pm 11 \%$ $(p=0.017)$, indicating that endogenous GABA was excitatory in a large population of neurons. Thus, spontaneous epileptiform discharges progressively reduce the rate of $G_{A B A}-R$-mediated
P5) hippocampus were loaded with the calcium indicator dye OGB (supplemental Fig. 1, available at www.jneurosci.org as supplemental material). Synchronous postsynaptic field potential responses and intracellular $\mathrm{Ca}^{2+}$ signals were induced by electrical stimulation in the stratum radiatum of CA3 area (Fig. 10d,e).

Under control conditions, electrical stimulation induced field EPSP and synchronous $\mathrm{Ca}^{2+}$ transients in hundreds of CA3 neurons (Fig. 10d). On average, excitatory cellular responses (transient increases in $\left[\mathrm{Ca}^{2+}\right]_{\mathrm{i}}$ measured as $\left.\Delta F / F\right)$ were detected in $62.2 \pm 12.0 \%$ of neurons ( 383 of 616 cells; $n=3$ recordings) with an average $\Delta F / F$ of $6.8 \pm 0.1 \%$ (Fig. 10f,g). We determined the degree to which synaptic excitation and inhibition contribute to these responses. Bath application of KYNA ( $2 \mathrm{~mm}$ ), in combination with CGP $55845(1 \mu \mathrm{M})$ depressed the evoked field EPSPs and intracellular $\mathrm{Ca}^{2+}$ signals. Under these conditions, increases in $\left[\mathrm{Ca}^{2+}\right]_{\mathrm{i}}$ in response to electrical stimulation were detected in only $14.5 \%$ of neurons ( 91 of 624 cells). In those cells that show increased $\left[\mathrm{Ca}^{2+}\right]_{\mathrm{i}}$, the average peak signal intensity was a $\Delta F / F$ of $4.3 \pm 0.2 \%$. Subsequent application of the $\mathrm{GABA}_{\mathrm{A}}-\mathrm{R}$ antagonist SR $95531(10 \mu \mathrm{M})$, in the presence of KYNA and CGP 55845, elicited an increase in the response to electrical stimulation measured by intracellular $\mathrm{Ca}^{2+}$ signals. Under these conditions, fluorescence calcium imaging revealed that both the percentage of 
responding cells $(73.5 \pm 12.0 \%)$ and the response amplitude $(\Delta F / F=14.5 \pm$ $0.4 \%)$ were significantly higher than under the previous conditions $(p<0.01$, ANOVA with post hoc correction) (Fig. $10 f, g)$. These evoked increases in calcium in the presence of glutamate and GABA antagonists were presumably attributable to direct electrical stimulation of dendrites. After washing out of drugs, transient application of SR 95531 ( $10 \mu \mathrm{M}$ for 5 min) induced sustained ictal-like epileptiform activity, followed by recurrent interictal and ictal-like epileptiform discharges. Under these conditions, 30-40 min after onset of spontaneous seizures, electrical stimulation induced epileptiform discharges and corresponding $\mathrm{Ca}^{2+}$ signals in $99.4 \%$ of all cells (Fig. $10 e-g$ ) ( 820 of 825 cells; $n=3$ recordings). These responses were, on average, significantly amplified compared with control $(\Delta F /$ $F=27.4 \pm 0.6 \% ; p<0.01$ ANOVA with post hoc). In line with previous data, bath application of KYNA (2 $\mathrm{mm}$ ) and CGP $55845(1 \mu \mathrm{M})$ abolished spontaneous and evoked epileptiform discharges and significantly decreased the percentage of responding cells $(34.2 \%)$ and the corresponding response amplitude $(\Delta F / F=$ $11.7 \pm 0.5 \%$ ) (Fig. 10f,g). Subsequent application of SR $95531(10 \mu \mathrm{M})$, in the presence of KYNA and CGP 55845, failed to increase either cellular response probability $(42.2 \%, 436$ of 1032 cells) or response amplitude $(\Delta F / F=12.4 \pm 0.5 \%$, 436 cells), indicating altered synaptic operation of the $\mathrm{GABA}_{\mathrm{A}}$ receptors. This is in contrast to the response elicited in control conditions, before seizure activity, in which block of $\mathrm{GABA}_{\mathrm{A}}-\mathrm{R}$ caused a dramatic rise of cellular response probability and $\Delta F / F$. Our data strongly suggest that neonatal seizures reduce the net inhibitory effect of endogenously released GABA.

The results described above do not differentiate whether GABA effects are homogenously reduced after seizures, as could occur from either a shift in $E_{\mathrm{GABA}}$ or a reduction in the postsynaptic GABA conductance response, or whether GABA became excitatory in only a subpopulation of neurons. We therefore coregistered our images from the control and afterseizure activity datasets and automatically detected those cells that were clearly identifiable under both conditions. We then developed a simple measure to determine whether any of those cells switched from being inhibited by GABA in control conditions to being non-inhibited or excited by GABA post-ictally (Fig. 10h). We determined in which cells the stimulus-induced calcium transient was increased after $\mathrm{GABA}_{\mathrm{A}}-\mathrm{R}$ blockade under control conditions and then, after spontaneous seizures, measured the fraction of those cells that still had an increase in stimulus-induced calcium transient after $\mathrm{GABA}_{\mathrm{A}}$ - $\mathrm{R}$ blockade. We found that cellular responses were not uniform: not all cells had a loss of GABA-mediated inhibition after spontaneous seizures. Blockade of $\mathrm{GABA}_{\mathrm{A}}-\mathrm{R}$ under these conditions still enhanced the $\mathrm{Ca}^{2+}$ signal in 224 of 423 cells $(p<0.001$, Mann-Whitney test), indicating that these cells were still inhibited by endogenously released GABA. The remaining 199 cells $(\sim 43 \%)$ switched post-ictally from being inhibited by endogenously released GABA to being excited or not inhibited by GABA [ $\chi^{2}$ test, 3 (inhibitory, neutral, excitatory) $\times 2$ (before seizures, after seizures), $p<0.001$ ]. Cells in this category demonstrated after block of $\mathrm{GABA}_{\mathrm{A}}$-Rs either no stimulusinduced change in the calcium transients (157 cells, $\sim 34 \%$; $p>0.05$, Mann-Whitney test) or significantly reduced calcium transients (42 cells, $\sim 9 \% ; p<0.05$, Mann-Whitney test). Thus, after spontaneous seizure activity, nearly half of all neurons undergo a transformation that causes them to lose their inhibitory response or switch their inhibitory response to endogenous GABA from inhibition to excitation. 
a

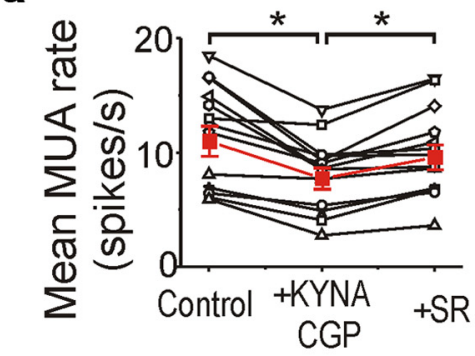

b

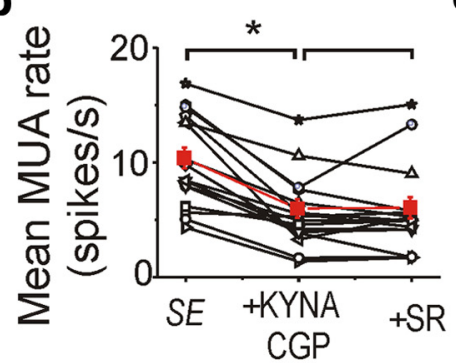

d
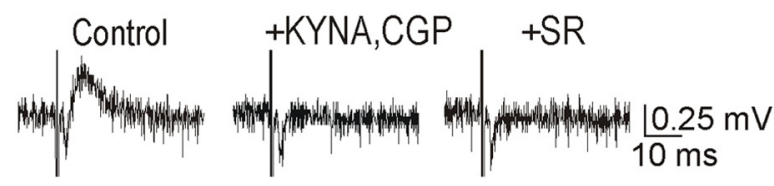

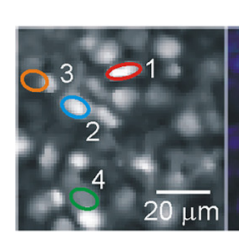

o Cell 1

o Cell 2

o Cell 3

o Cell 4

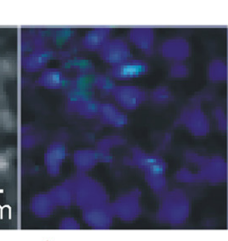

Mrumanim

Minminim

Nhrming

01020
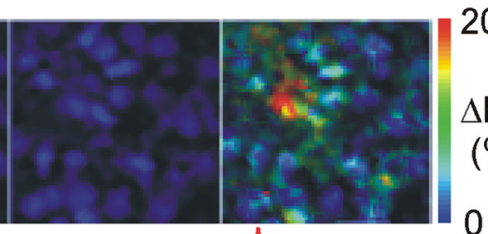

20

$\Delta \mathrm{F} / \mathrm{F}$

$(\%)$
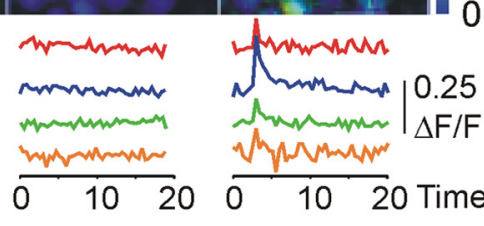

0

9

$(\mathrm{s})$
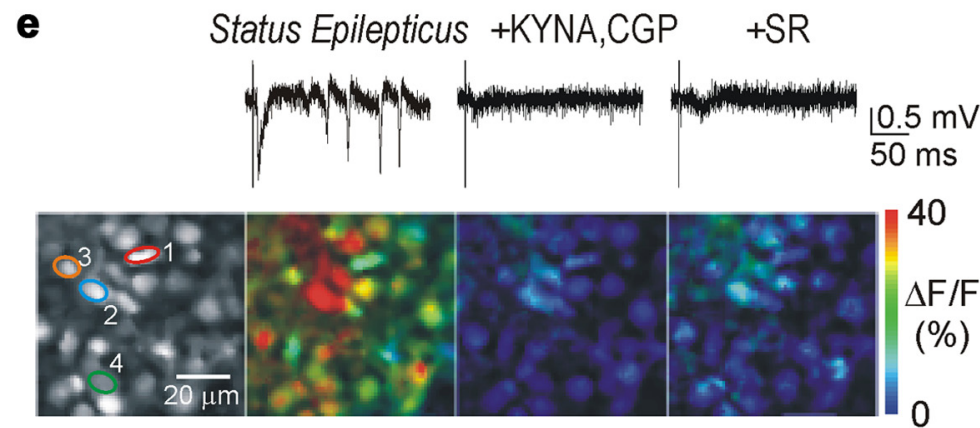

o Cell 1

o Cell 2

o Cell 3

o Cell 4
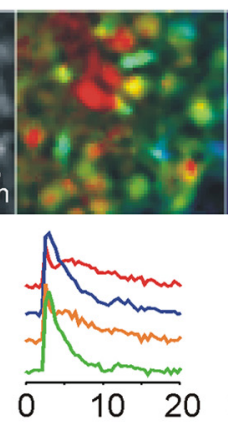

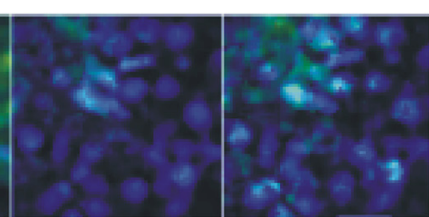

1

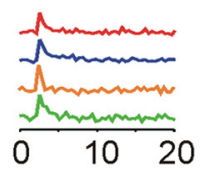

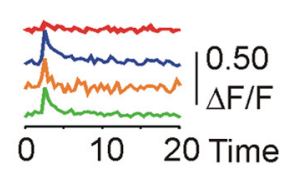

40

h
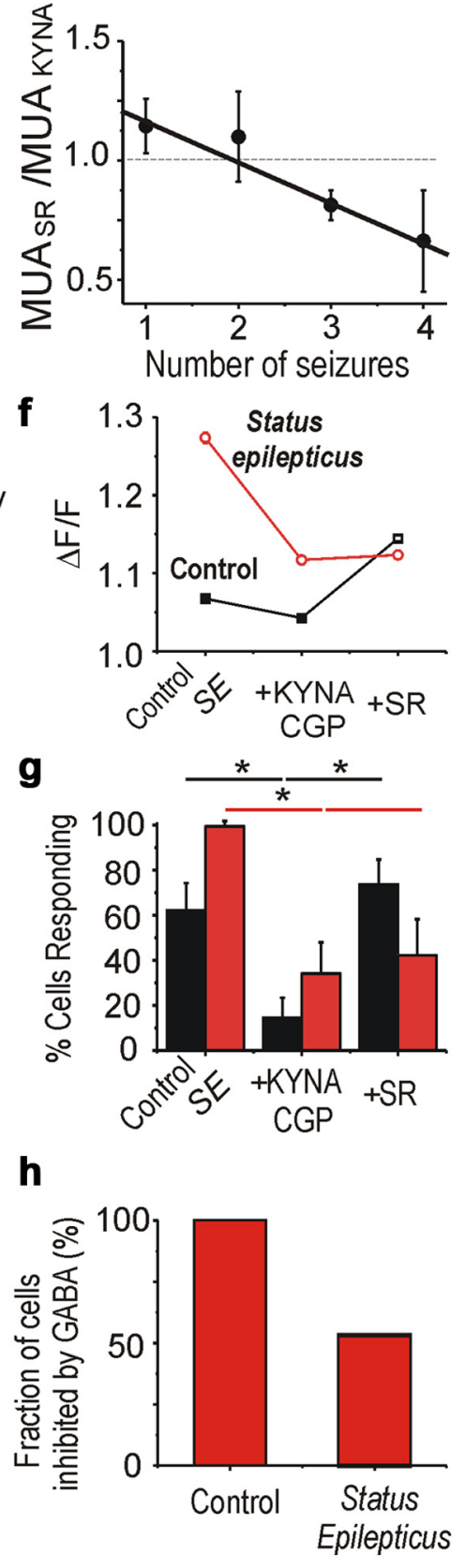

Figure 10. Neonatal seizures alter the effect of synaptic activation of $G_{A B A}$ receptors. $\boldsymbol{a}-\boldsymbol{c}$, Effects on spontaneous neuronal firing rate of suppressing synaptic excitation and inhibition in control and during seizures. In control (a), KYNA (2 mM) coapplied with CGP 55845 (CGP; $1 \mu \mathrm{M}$ ) reduced the mean frequency of MUA in the CA3 pyramidal cell layer in the intact neonatal hippocampi at $P 4-P 5$. Subsequent application of the $G A B A_{A}-R$ antagonist SR 95531 (SR), in the presence of KYNA and CGP 55845, increased MUA frequency, demonstrating the net inhibitory effect of $G A B A_{A}-R$ when activated by endogenously released GABA. $\boldsymbol{b}$, Spontaneous seizures were induced by brief (2-3 min) application of SR 95531 . After 30 min of spontaneous seizure activity after washout of SR 95531, application of KYNA and CGP 55845 stopped recurrent seizures and reduced MUA frequency. Subsequent application of SR 95531 did not change the mean frequency of MUA. Red plots represent the averaged mean frequency of MUA. SE, Status epilepticus. c, Mean ratio of MUA frequency [SR 95531/(KYNA + CGP 55845)] reversed as a function of the number of seizures. Solid line represents corresponding linear regression fit $(r=-0.98 ; p=0.02) . \boldsymbol{d}, \boldsymbol{e}$, Synchronous extracellular field potentials and two-photon fluorescence $\left[\mathrm{Ca}^{2+}\right]_{\mathrm{i}}$ imaging in the $\mathrm{CA}_{3}$ pyramidal cell layer at P5 in the intact hippocampal preparation. Neurons were labeled by the calcium indicator dye 0 GB. Field EPSPs and intracellular calcium signals were induced by electrical stimulation in the stratum radiatum proximal of the CA3 area. In control (d), bath application of KYNA ( $2 \mathrm{~mm})$ and CGP $55845(1 \mu \mathrm{m})$ depressed calcium signals ( $\Delta F / F)$ in the majority of CA3 neurons. Subsequent application of SR $95531(10 \mu \mathrm{M})$, in the presence of KYNA and CGP 55845, increased $\Delta$ F/Fin the majority of the cells. The increase in Ca ${ }^{2+}$ in the presence of ionotropic glutamate and GABA receptor antagonists likely represents metabotropic receptor activation and direct electrical stimulation. $\boldsymbol{e}$, After spontaneous seizures, the effect of $S R 95531$ on $\Delta F / F$ was reversed in $\sim 50 \%$ of neurons. $\boldsymbol{f}, \boldsymbol{g}$, Mean population response $(\Delta F / F)$ and fraction of cells with a stimulus-induced increase in calcium responses during applications of drugs in control and after spontaneous seizures. ${ }^{*} p<0.05 . \boldsymbol{h}$, After recurrent seizure activity, nearly half of neurons lose their inhibitory response to endogenous GABA or switch their inhibitory response from inhibition to excitation.

\section{Discussion}

Our results demonstrate that NKCC1 activity strongly contributes to the intracellular chloride accumulation induced by recurrent seizures (Figs. 2, 5; Table 2). Activity-dependent shifts in
$\left[\mathrm{K}^{+}\right]_{\mathrm{o}}$ (Moody et al., 1974; Heinemann et al., 1977), which alter the $\left[\mathrm{Cl}^{-}\right]_{\mathrm{i}}$ at which NKCC1 comes to equilibrium, are sufficient to cause these short-term changes in $\left[\mathrm{Cl}^{-}\right]_{i}$ (Fig. 7), although other mechanisms may also be important. As a consequence, 
there is a sustained switch in the net effect of $\mathrm{GABA}_{\mathrm{A}}-\mathrm{R}$ activation from inhibition to excitation (Figs. 3, 6, 9). Shifts in $E_{\mathrm{Cl}}$ and GABA action contribute to facilitation of recurrent seizures and additional chloride accumulation. Under these conditions, recurrent seizures respond less well to GABAergic anticonvulsants and better to the NKCC1 antagonist bumetanide, particularly when administered in combination with a positive allosteric GABA receptor modulator such as phenobarbital (Dzhala et al., 2008). Our data provide mechanistic insights into GABAergic excitation during neonatal seizures (Derchansky et al., 2008).

We demonstrated previously the anticonvulsant effects of bumetanide in a model of neonatal seizures in vitro (Dzhala et al., 2005,2008 ). The reduced efficacy of bumetanide in other in vitro models of neonatal seizures (Kilb et al., 2007) likely reflects differences in the number of seizures before administration of bumetanide because, as predicted by the ictal, NKCC1-mediated increase in $\left[\mathrm{Cl}^{-}\right]_{\mathrm{i}}$ (Fig. 5) and as illustrated in supplemental Figure 3 (available at www.jneurosci.org as supplemental material), the anticonvulsant efficacy of bumetanide increases as a function of the number of seizures experienced by the preparation. Experimental data regarding the efficacy of GABA-enhancing anticonvulsants in neonatal seizures are controversial (Table 1). Some of this controversy may arise as a consequence of the heterogeneous values of $E_{\mathrm{GABA}}$ in the developing cortical networks (Figs. 1, 2, 5, 7 ), such that the net actions of GABAergic agents in a particular slice preparation might be similarly varied. In addition, the ictal time course of changes in neuronal $\mathrm{Cl}^{-}$are important experimental variables. In vivo models of neonatal seizures, primarily induced by GABA antagonists, demonstrate efficacy of GABAergic anticonvulsants administered before or coincident with convulsants (Velísek et al., 1995; Haugvicova et al., 1999; Isaev et al., 2007). As demonstrated in Figures 1-4, administration of phenobarbital before or just after the first seizure, when $\left[\mathrm{Cl}^{-}\right]_{\mathrm{i}}$ is relatively low and the net effect of GABA is still inhibitory, may prevent or reduce the positive feedback cycle of seizure-dependent disinhibition and subsequent disinhibition-induced seizures that limit the subsequent efficacy of GABAergic anticonvulsants.

Several mechanisms may be involved in activation of NKCC1 during recurrent seizure activity. NKCC1 activity is thought to be increased by phosphorylation (Darman and Forbush, 2002) and decreased by protein phosphatase 1-mediated dephosphorylation (Gagnon et al., 2007). NKCC1 phosphorylation corresponded to an increase in intracellular chloride in an in vitro model of ischemia (Pond et al., 2006). Our data (supplemental Fig. 4, available at www.jneurosci.org as supplemental material) provide no indication that NKCC1 phosphorylation is increased by seizure activity but do not address total NKCC1 protein levels nor membrane trafficking. However, under conditions studied so far, activity-dependent increases in NKCC1-mediated $\mathrm{Cl}^{-}$accumulation do not involve changes in $\mathrm{NKCC} 1$ maximum velocity or affinity for chloride but rather changes in the transmembrane ion gradients of the cotransported cations (Brumback and Staley, 2008 ), i.e., they do not involve alteration in total NKCC1 protein, NKCC1 membrane trafficking, or changes in NKCC1 phosphorylation (supplemental Fig. 4, available at www.jneurosci.org as supplemental material).

$\left[\mathrm{K}^{+}\right]_{\mathrm{o}}$ increases during seizures (Prince et al., 1973; Fisher et al., 1976; Khalilov et al., 1999b), and elevated $\left[\mathrm{K}^{+}\right]_{\mathrm{o}}$ markedly alters the driving force for transmembrane $\mathrm{Cl}^{-}$cotransport (Thompson and Gähwiler, 1989; Staley and Proctor, 1999; Blaesse et al., 2009). This shift in free energy would be expected to lead to a corresponding increase in the $\left[\mathrm{Cl}^{-}\right]_{\mathrm{i}}$ at which NKCC1 reached equilibrium (Brumback and Staley, 2008) and would thus drive $\mathrm{Cl}^{-}$influx via NKCC1 (Sun and Murali, 1998). Our experiments with increased $\left[\mathrm{K}^{+}\right]_{\mathrm{o}}$ strongly support this mechanism (Fig. 7) but do not exclude the possibility of additional mechanisms of modulation of NKCC1 and chloride accumulation.

Finally, paroxysmal depolarizing shifts in the membrane potential during seizures will induce $\mathrm{Cl}^{-}$accumulation through open $\mathrm{GABA}_{\mathrm{A}}$-Rs; this phenomenon has been frequently exploited experimentally to load neurons with $\mathrm{Cl}^{-}$(Staley and Proctor, 1999; Brumback and Staley, 2008). Such a mechanism may contribute to the small NKCC1-independent ictal increase in $\left[\mathrm{Cl}^{-}\right]_{\mathrm{i}}$ (Fig. $5 B$ ).

All differential interference contrast patch clampers select neurons to patch based on visual criteria related to cell turgor. Given the strong relationship between the activities of cationchloride cotransporters and cell volume (Kahle et al., 2008), turgor is likely to be strongly correlated with neuronal chloride concentration. Patchable cells represent a very small subset of all neurons imaged with Clomeleon. Our results using Clomeleon extend the spectrum of actions of GABA during postnatal development (Ben-Ari et al., 2007) by demonstrating the wide range of $\left[\mathrm{Cl}^{-}\right]_{\mathrm{i}}$ and GABA effects in individual neurons in the developing hippocampus. Our data also underscore the importance of the history of activity of the preparation on neuronal $\left[\mathrm{Cl}^{-}\right]_{\mathrm{i}}$ and the consequent effects of $\mathrm{GABA}_{\mathrm{A}}$ receptor activation. Our findings are consistent with previous observations of shifts in $E_{\mathrm{GABA}}$ as a consequence of trains of action potentials (Woodin et al., 2003; Brumback and Staley, 2008), seizures (Khalilov et al., 2003), trauma (van den Pol et al., 1996; Nabekura et al., 2002), and hypoxia (Pond et al., 2006). These long-term, experiencedependent shifts in $E_{\mathrm{GABA}}$ may explain the incongruent results that have been obtained in developing preparations (Table 1).

The opposite effects of the $\mathrm{GABA}_{\mathrm{A}}-\mathrm{R}$ activation in the intact hippocampal preparations versus the hippocampal slices probably arise from acute traumatic neuronal damage during slicing that may cause an increase in intracellular $\mathrm{Cl}^{-}$concentration and consequent inversion of GABA action (van den Pol et al., 1996; Nabekura et al., 2002). Our results support reports of a predominantly inhibitory hyperpolarizing effect of $\mathrm{GABA}_{\mathrm{A}}$ receptors in the neonatal hippocampus in vivo (Isaev et al., 2007). Additionally, perinatal hippocampal slice studies of the effects of $\mathrm{GABA}_{\mathrm{A}}-\mathrm{R}$ activation on $\left[\mathrm{Ca}^{2+}\right]_{\mathrm{i}}$ in CA3 neurons estimate that $50 \%$ of P 5 neurons are not excited by GABA (Tyzio et al., 2006), in agreement with Figure 10.

The biphasic effects of the $\mathrm{GABA}_{\mathrm{A}}-\mathrm{R}$ agonist isoguvacine on network action potential frequency (Figs. 3, 8, 9) likely represents activity-dependent shift in $E_{\mathrm{GABA}}$. When NKCC1 is active and $E_{\mathrm{GABA}}$ is positive to membrane potential, low initial concentrations of isoguvacine activate $\mathrm{GABA}_{\mathrm{A}}$ receptors and depolarize neurons. Subsequently, GABA channels are opened so persistently that the high fluxes of chloride overwhelm NKCC1mediated chloride transport (Dzhala and Staley, 2003; Brumback and Staley, 2008). The clinical correlate of this experimental finding is that very high concentrations of GABAergic anticonvulsants are effective treatments of neonatal seizures (Mizrahi and Kellaway, 1987), presumably via the same mechanism: overwhelming NKCC1-mediated $\mathrm{Cl}^{-}$transport with chloride flux though persistently opened $\mathrm{GABA}_{\mathrm{A}}$-R-operated ion channels. The consequent passive transmembrane distribution of $\mathrm{Cl}^{-}$, together with the low membrane resistivity induced by persistent $\mathrm{GABA}_{\mathrm{A}}-\mathrm{R}$ activation, permits effective shunting inhibition. The potential disadvantage of using high doses of GABAergic anticonvulsants to treat neonatal 
seizures is the level of GABA-mediated suppression of brainstem and spinal circuits that have already undergone the developmental switch from NKCC1-mediated neuronal $\mathrm{Cl}^{-}$import to KCC2mediated neuronal $\mathrm{Cl}^{-}$export (Stein et al., 2004; Glykys et al., 2009), as well as increased anticonvulsant-induced neuronal apoptosis (Ikonomidou, 2009). Although there are also potentially deleterious effects of NKCC1 inhibition (Ge et al., 2006; Cancedda et al., 2007; Wang et al., 2008), these are evident after much more prolonged inhibition than would be necessary to control most neonatal seizures (Painter et al., 1999).

Recurrent seizures in neonatal and adult cortical structures cause activity-dependent alterations in ion concentrations (Fisher et al., 1976; Cohen et al., 2002; Khalilov et al., 2003; Galanopoulou, 2008; Li et al., 2008). Here we demonstrate that changes in ion transport persist beyond the end of seizure activity to contribute to recurrence of seizures. These findings are of particular interest in understanding the natural history of neonatal seizures. Prospective EEG studies in which clinically silent electrographic seizures were untreated (Connell et al., 1989) support the clinical impression that seizures attributable to brain injury begin hours after the insult and continue for $\sim 72 \mathrm{~h}$ (Volpe, 2001). The NKCC1-mediated delayed increase in neuronal chloride concentration after hypoxic/aglycemic injury (Pond et al., 2006) together with the observation that increases in NKCC1 transcription persist for $72 \mathrm{~h}$ after injury in vivo (Dai et al., 2005) support the hypothesis that increases in NKCC1 activity and consequent compromise of GABA-mediated inhibition contribute significantly to the time course of neonatal seizures after hypoxic-ischemic brain injury (Cowan et al., 2003; Tekgul et al., 2006). Induction of NKCC1 by hypoxic injury may explain why rapid EEG diagnosis and treatment of neonatal seizures has not had a bigger impact on the efficacy of phenobarbital therapy (Painter et al., 1999; Bartha et al., 2007), as might be predicted from Figure 2. By the time the first seizure has occurred, NKCC1 activity may already be increased as a result of the previous hypoxia so that early treatment with phenobarbital is still too late to rescue $\mathrm{GABA}_{\mathrm{A}}-\mathrm{R}$-mediated inhibition. An open question is whether prophylactic treatment with bumetanide would reduce the incidence or severity of neonatal seizures.

\section{References}

Abegg MH, Savic N, Ehrengruber MU, McKinney RA, Gähwiler BH (2004) Epileptiform activity in rat hippocampus strengthens excitatory synapses. J Physiol 554:439-448.

Arnold FJ, Hofmann F, Bengtson CP, Wittmann M, Vanhoutte P, Bading H (2005) Microelectrode array recordings of cultured hippocampal networks reveal a simple model for transcription and protein synthesisdependent plasticity. J Physiol 564:3-19.

Bains JS, Longacher JM, Staley KJ (1999) Reciprocal interactions between CA3 network activity and strength of recurrent collateral synapses. Nat Neurosci 2:720-726.

Bartha AI, Shen J, Katz KH, Mischel RE, Yap KR, Ivacko JA, Andrews EM, Ferriero DM, Ment LR, Silverstein FS (2007) Neonatal seizures: multicenter variability in current treatment practices. Pediatr Neurol 37:85-90.

Ben-Ari Y, Gho M (1988) Long-lasting modification of the synaptic properties of rat CA3 hippocampal neurones induced by kainic acid. J Physiol 404:365-384.

Ben-Ari Y, Gaiarsa JL, Tyzio R, Khazipov R (2007) GABA: a pioneer transmitter that excites immature neurons and generates primitive oscillations. Physiol Rev 87:1215-1284.

Berglund K, Schleich W, Wang H, Feng G, Hall WC, Kuner T, Augustine GJ (2008) Imaging synaptic inhibition throughout the brain via genetically targeted Clomeleon. Brain Cell Biol 36:101-118.

Blaesse P, Airaksinen MS, Rivera C, Kaila K (2009) Cation-chloride cotransporters and neuronal function. Neuron 61:820-838.

Brumback AC, Staley KJ (2008) Thermodynamic regulation of NKCC1- mediated $\mathrm{Cl}^{-}$cotransport underlies plasticity of $\mathrm{GABA}_{\mathrm{A}}$ signaling in neonatal neurons. J Neurosci 28:1301-1312.

Cancedda L, Fiumelli H, Chen K, Poo MM (2007) Excitatory GABA action is essential for morphological maturation of cortical neurons in vivo. J Neurosci 27:5224-5235.

Carmo KB, Barr P (2005) Drug treatment of neonatal seizures by neonatologists and paediatric neurologists. J Paediatr Child Health 41:313-316.

Cohen I, Miles R (2000) Contributions of intrinsic and synaptic activities to the generation of neuronal discharges in in vitro hippocampus. J Physiol 524:485-502.

Cohen I, Navarro V, Clemenceau S, Baulac M, Miles R (2002) On the origin of interictal activity in human temporal lobe epilepsy in vitro. Science 298:1418-1421.

Connell J, Oozeer R, de Vries L, Dubowitz LM, Dubowitz V (1989) Clinical and EEG response to anticonvulsants in neonatal seizures. Arch Dis Child 64:459-464.

Cowan F, Rutherford M, Groenendaal F, Eken P, Mercuri E, Bydder GM, Meiners LC, Dubowitz LM, de Vries LS (2003) Origin and timing of brain lesions in term infants with neonatal encephalopathy. Lancet 361:736-742.

Dai Y, Tang J, Zhang JH (2005) Role of $\mathrm{Cl}^{-}$in cerebral vascular tone and expression of $\mathrm{Na}^{+}-\mathrm{K}^{+}-2 \mathrm{Cl}^{-}$co-transporter after neonatal hypoxiaischemia. Can J Physiol Pharmacol 83:767-773.

Darman RB, Forbush B (2002) A regulatory locus of phosphorylation in the $\mathrm{N}$ terminus of the Na-K-Cl cotransporter, NKCC1. J Biol Chem 277:37542-37550.

Delpire E (2000) Cation-chloride cotransporters in neuronal communication. News Physiol Sci 15:309-312.

Derchansky M, Jahromi SS, Mamani M, Shin DS, Sik A, Carlen PL (2008) Transition to seizures in the isolated immature mouse hippocampus: a switch from dominant phasic inhibition to dominant phasic excitation. J Physiol 586:477-494.

Duebel J, Haverkamp S, Schleich W, Feng G, Augustine GJ, Kuner T, Euler T (2006) Two-photon imaging reveals somatodendritic chloride gradient in retinal ON-type bipolar cells expressing the biosensor Clomeleon. Neuron 49:81-94.

Dzhala VI, Staley KJ (2003) Excitatory actions of endogenously released GABA contribute to initiation of ictal epileptiform activity in the developing hippocampus. J Neurosci 23:1840-1846.

Dzhala VI, Talos DM, Sdrulla DA, Brumback AC, Mathews GC, Benke TA, Delpire E, Jensen FE, Staley KJ (2005) NKCC1 transporter facilitates seizures in the developing brain. Nat Med 11:1205-1213.

Dzhala VI, Brumback AC, Staley KJ (2008) Bumetanide enhances phenobarbital efficacy in a neonatal seizure model. Ann Neurol 63:222-235.

Fisher RS, Pedley TA, Moody WJ Jr, Prince DA (1976) The role of extracellular potassium in hippocampal epilepsy. Arch Neurol 33:76-83.

Fiumelli H, Woodin MA (2007) Role of activity-dependent regulation of neuronal chloride homeostasis in development. Curr Opin Neurobiol 17:81-86.

Flemmer AW, Gimenez I, Dowd BF, Darman RB, Forbush B (2002) Activation of the Na-K-Cl cotransporter NKCC1 detected with a phosphospecific antibody. J Biol Chem 277:37551-37558.

Gagnon KB, England R, Diehl L, Delpire E (2007) Apoptosis-associated tyrosine kinase scaffolding of protein phosphatase 1 and SPAK reveals a novel pathway for $\mathrm{Na}-\mathrm{K}-2 \mathrm{Cl}$ cotransporter regulation. Am J Physiol Cell Physiol 292:C1809-C1815.

Galanopoulou AS (2008) Dissociated gender-specific effects of recurrent seizures on GABA signaling in CA1 pyramidal neurons: role of $\mathrm{GABA}_{\mathrm{A}}$ receptors. J Neurosci 28:1557-1567.

Gamba G (2005) Molecular physiology and pathophysiology of electroneutral cation-chloride cotransporters. Physiol Rev 85:423-493.

Ge S, Goh EL, Sailor KA, Kitabatake Y, Ming GL, Song H (2006) GABA regulates synaptic integration of newly generated neurons in the adult brain. Nature 439:589-593.

Giménez I, Forbush B (2003) Short-term stimulation of the renal Na-K-Cl cotransporter (NKCC2) by vasopressin involves phosphorylation and membrane translocation of the protein. J Biol Chem 278:26946-26951.

Glykys J, Dzhala VI, Kuchibhotla KV, Feng G, Kuner T, Augustine G, Bacskai BJ, Staley KJ (2009) Differences in cortical versus subcortical GABAergic signaling: a candidate mechanism of electroclinical uncoupling of neonatal seizures. Neuron 63:657-672.

Goodkin HP, Joshi S, Mtchedlishvili Z, Brar J, Kapur J (2008) Subunit- 
specific trafficking of $\mathrm{GABA}_{\mathrm{A}}$ receptors during status epilepticus. J Neurosci 28:2527-2538.

Hannaert P, Alvarez-Guerra M, Pirot D, Nazaret C, Garay RP (2002) Rat NKCC2/NKCC1 cotransporter selectivity for loop diuretic drugs. Naunyn Schmiedebergs Arch Pharmacol 365:193-199.

Haugvicová R, Kubová H, Mares P (1999) Antipentylenetetrazol action of clobazam in developing rats. Physiol Res 48:501-507.

Heinemann U, Lux HD, Gutnick MJ (1977) Extracellular free calcium and potassium during paroxsmal activity in the cerebral cortex of the cat. Exp Brain Res 27:237-243.

Hirsch JC, Agassandian C, Merchán-Pérez A, Ben-Ari Y, DeFelipe J, Esclapez M, Bernard C (1999) Deficit of quantal release of GABA in experimental models of temporal lobe epilepsy. Nat Neurosci 2:499-500.

Ikonomidou C (2009) Triggers of apoptosis in the immature brain. Brain Dev 31:488-492.

Isaev D, Isaeva E, Khazipov R, Holmes GL (2007) Shunting and hyperpolarizing GABAergic inhibition in the high-potassium model of ictogenesis in the developing rat hippocampus. Hippocampus 17:210-219.

Isenring P, Jacoby SC, Payne JA, Forbush B 3rd (1998) Comparison of Na$\mathrm{K}-\mathrm{Cl}$ cotransporters. NKCC1, NKCC2, and the HEK cell Na-L-Cl cotransporter. J Biol Chem 273:11295-11301.

Jin X, Huguenard JR, Prince DA (2005) Impaired $\mathrm{Cl}^{-}$extrusion in layer $\mathrm{V}$ pyramidal neurons of chronically injured epileptogenic neocortex. J Neurophysiol 93:2117-2126.

Kahle KT, Staley KJ, Nahed BV, Gamba G, Hebert SC, Lifton RP, Mount DB (2008) Roles of the cation-chloride cotransporters in neurological disease. Nat Clin Pract Neurol 4:490-503.

Khalilov I, Esclapez M, Medina I, Aggoun D, Lamsa K, Leinekugel X, Khazipov R, Ben-Ari Y (1997) A novel in vitro preparation: the intact hippocampal formation. Neuron 19:743-749.

Khalilov I, Dzhala V, Ben-Ari Y, Khazipov R (1999a) Dual role of GABA in the neonatal rat hippocampus. Dev Neurosci 21:310-319.

Khalilov I, Dzhala V, Medina I, Leinekugel X, Melyan Z, Lamsa K, Khazipov R, Ben-Ari Y (1999b) Maturation of kainate-induced epileptiform activities in interconnected intact neonatal limbic structures in vitro. Eur J Neurosci 11:3468-3480.

Khalilov I, Holmes GL, Ben-Ari Y (2003) In vitro formation of a secondary epileptogenic mirror focus by interhippocampal propagation of seizures. Nat Neurosci 6:1079-1085.

Khazipov R, Khalilov I, Tyzio R, Morozova E, Ben-Ari Y, Holmes GL (2004) Developmental changes in GABAergic actions and seizure susceptibility in the rat hippocampus. Eur J Neurosci 19:590-600.

Kilb W, Sinning A, Luhmann HJ (2007) Model-specific effects of bumetanide on epileptiform activity in the in vitro intact hippocampus of the newborn mouse. Neuropharmacology 53:524-533.

Kuner T, Augustine GJ (2000) A genetically encoded ratiometric indicator for chloride: capturing chloride transients in cultured hippocampal neurons. Neuron 27:447-459.

Li X, Zhou J, Chen Z, Chen S, Zhu F, Zhou L (2008) Long-term expressional changes of $\mathrm{Na}^{+}-\mathrm{K}^{+}-\mathrm{Cl}^{-}$co-transporter 1 (NKCC1) and $\mathrm{K}^{+}-\mathrm{Cl}^{-}$cotransporter 2 (KCC2) in CA1 region of hippocampus following lithiumpilocarpine induced status epilepticus (PISE). Brain Res 1221:141-146.

Mazarati A, Shin D, Sankar R (2009) Bumetanide inhibits rapid kindling in neonatal rats. Epilepsia 50:2117-2122.

Mizrahi EM, Kellaway P (1987) Characterization and classification of neonatal seizures. Neurology 37:1837-1844.

Moody WJ, Futamachi KJ, Prince DA (1974) Extracellular potassium activity during epileptogenesis. Exp Neurol 42:248-263.

Nabekura J, Ueno T, Okabe A, Furuta A, Iwaki T, Shimizu-Okabe C, Fukuda A, Akaike N (2002) Reduction of KCC2 expression and $\mathrm{GABA}_{\mathrm{A}}$ receptor-mediated excitation after in vivo axonal injury. J Neurosci 22:4412-4417.

Nardou R, Ben-Ari Y, Khalilov I (2009) Bumetanide, an NKCC1 antagonist, does not prevent formation of epileptogenic focus but blocks epileptic focus seizures in immature rat hippocampus. J Neurophysiol 101:2878-2888.

Naylor DE, Liu H, Wasterlain CG (2005) Trafficking of $\mathrm{GABA}_{\mathrm{A}}$ receptors, loss of inhibition, and a mechanism for pharmacoresistance in status epilepticus. J Neurosci 25:7724-7733.

Painter MJ, Scher MS, Stein AD, Armatti S, Wang Z, Gardiner JC, Paneth N, Minnigh B, Alvin J (1999) Phenobarbital compared with phenytoin for the treatment of neonatal seizures. N Engl J Med 341:485-489.
Pathak HR, Weissinger F, Terunuma M, Carlson GC, Hsu FC, Moss SJ, Coulter DA (2007) Disrupted dentate granule cell chloride regulation enhances synaptic excitability during development of temporal lobe epilepsy. J Neurosci 27:14012-14022.

Payne JA (1997) Functional characterization of the neuronal-specific K-Cl cotransporter: implications for $[\mathrm{K}+]_{\mathrm{o}}$ regulation. Am J Physiol 273: C1516-C1525.

Payne JA, Rivera C, Voipio J, Kaila K (2003) Cation-chloride cotransporters in neuronal communication, development and trauma. Trends Neurosci 26:199-206.

Pond BB, Berglund K, Kuner T, Feng G, Augustine GJ, Schwartz-Bloom RD (2006) The chloride transporter $\mathrm{Na}^{+}-\mathrm{K}^{+}-\mathrm{Cl}^{-}$cotransporter isoform-1 contributes to intracellular chloride increases after in vitro ischemia. J Neurosci 26:1396-1406.

Prince DA, Lux HD, Neher E (1973) Measurement of extracellular potassium activity in cat cortex. Brain Res 50:489-495.

Qian N, Sejnowski TJ (1990) When is an inhibitory synapse effective? Proc Natl Acad Sci U S A 87:8145-8149.

Quilichini PP, Diabira D, Chiron C, Ben-Ari Y, Gozlan H (2002) Persistent epileptiform activity induced by low $\mathrm{Mg}^{2+}$ in intact immature brain structures. Eur J Neurosci 16:850-860.

Quilichini PP, Diabira D, Chiron C, Milh M, Ben-Ari Y, Gozlan H (2003) Effects of antiepileptic drugs on refractory seizures in the intact immature corticohippocampal formation in vitro. Epilepsia 44:1365-1374.

Raol YH, Lapides DA, Keating JG, Brooks-Kayal AR, Cooper EC (2009) A KCNQ channel opener for experimental neonatal seizures and status epilepticus. Ann Neurol 65:326-336.

Rennie JM, Boylan GB (2003) Neonatal seizures and their treatment. Curr Opin Neurol 16:177-181.

Rheims S, Minlebaev M, Ivanov A, Represa A, Khazipov R, Holmes GL, Ben-Ari Y, Zilberter Y (2008) Excitatory GABA in rodent developing neocortex in vitro. J Neurophysiol 100:609-619.

Schneiderman JH, Sterling CA, Luo R (1994) Hippocampal plasticity following epileptiform bursting produced by $\mathrm{GABA}_{\mathrm{A}}$ antagonists. Neuroscience 59:259-273.

Sipilä ST, Schuchmann S, Voipio J, Yamada J, Kaila K (2006) The cationchloride cotransporter NKCC1 promotes sharp waves in the neonatal rat hippocampus. J Physiol 573:765-773.

Staley K, Smith R (2001) A new form of feedback at the $\mathrm{GABA}_{\mathrm{A}}$ receptor. Nat Neurosci 4:674-676.

Staley KJ, Mody I (1992) Shunting of excitatory input to dentate gyrus granule cells by a depolarizing $\mathrm{GABA}_{\mathrm{A}}$ receptor-mediated postsynaptic conductance. J Neurophysiol 68:197-212.

Staley KJ, Proctor WR (1999) Modulation of mammalian dendritic GABA receptor function by the kinetics of $\mathrm{Cl}^{-}$and. J Physiol 519:693-712.

Stein V, Hermans-Borgmeyer I, Jentsch TJ, Hübner CA (2004) Expression of the $\mathrm{KCl}$ cotransporter KCC2 parallels neuronal maturation and the emergence of low intracellular chloride. J Comp Neurol 468:57-64.

Stosiek C, Garaschuk O, Holthoff K, Konnerth A (2003) In vivo two-photon calcium imaging of neuronal networks. Proc Natl Acad Sci U S A 100:7319-7324.

Sun D, Murali SG (1998) Stimulation of $\mathrm{Na}^{+}-\mathrm{K}^{+}-2 \mathrm{Cl}^{-}$cotransporter in neuronal cells by excitatory neurotransmitter glutamate. Am J Physiol 275:C772-C779.

Tekgul H, Gauvreau K, Soul J, Murphy L, Robertson R, Stewart J, Volpe J, Bourgeois B, du Plessis AJ (2006) The current etiologic profile and neurodevelopmental outcome of seizures in term newborn infants. Pediatrics 117:1270-1280.

Thompson SM, Gähwiler BH (1989) Activity-dependent disinhibition. II. Effects of extracellular potassium, furosemide, and membrane potential on $\mathrm{ECl}^{-}$in hippocampal CA3 neurons. J Neurophysiol 61:512-523.

Twyman RE, Rogers CJ, Macdonald RL (1989) Differential regulation of gamma-aminobutyric acid receptor channels by diazepam and phenobarbital. Ann Neurol 25:213-220.

Tyzio R, Ivanov A, Bernard C, Holmes GL, Ben-Ari Y, Khazipov R (2003) Membrane potential of CA3 hippocampal pyramidal cells during postnatal development. J Neurophysiol 90:2964-2972.

Tyzio R, Cossart R, Khalilov I, Minlebaev M, Hübner CA, Represa A, Ben-Ari Y, Khazipov R (2006) Maternal oxytocin triggers a transient inhibitory switch in GABA signaling in the fetal brain during delivery. Science 314:1788-1792.

Tyzio R, Holmes GL, Ben-Ari Y, Khazipov R (2007) Timing of the develop- 
mental switch in $\mathrm{GABA}_{\mathrm{A}}$ mediated signaling from excitation to inhibition in CA3 rat hippocampus using gramicidin perforated patch and extracellular recordings. Epilepsia 48 [Suppl 5]:96-105.

van den Pol AN, Obrietan K, Chen G (1996) Excitatory actions of GABA after neuronal trauma. J Neurosci 16:4283-4292.

Velísek L, Velísková J, Ptachewich Y, Ortíz J, Shinnar S, Moshé SL (1995) Age-dependent effects of gamma-aminobutyric acid agents on flurothyl seizures. Epilepsia 36:636-643.

Volpe JJ (2001) Neurology of the newborn. Philadelphia: Saunders.

Wang C, Shimizu-Okabe C, Watanabe K, Okabe A, Matsuzaki H, Ogawa T, Mori N, Fukuda A, Sato K (2002) Developmental changes in KCC1, KCC2, and NKCC1 mRNA expressions in the rat brain. Brain Res Dev Brain Res 139:59-66.

Wang DD, Kriegstein AR, Ben-Ari Y (2008) GABA regulates stem cell proliferation before nervous system formation. Epilepsy Curr 8:137-139.
Wells JE, Porter JT, Agmon A (2000) GABAergic inhibition suppresses paroxysmal network activity in the neonatal rodent hippocampus and neocortex. J Neurosci 20:8822-8830.

Woodin MA, Ganguly K, Poo MM (2003) Coincident pre-and postsynaptic activity modifies GABAergic synapses by postsynaptic changes in $\mathrm{Cl}^{-}$ transporter activity. Neuron 39:807-820.

Xiong ZQ, Stringer JL (2000) Sodium pump activity, not glial spatial buffering, clears potassium after epileptiform activity induced in the dentate gyrus. J Neurophysiol 83:1443-1451.

Xiong ZQ, Saggau P, Stringer JL (2000) Activity-dependent intracellular acidification correlates with the duration of seizure activity. J Neurosci 20:1290-1296.

Yamada J, Okabe A, Toyoda H, Kilb W, Luhmann HJ, Fukuda A (2004) $\mathrm{Cl}^{-}$ uptake promoting depolarizing GABA actions in immature rat neocortical neurones is mediated by NKCC1. J Physiol 557:829-841. 